NBER WORKING PAPER SERIES

\title{
THE INDUSTRY LIFE CYCLE, ACQUISITIONS AND INVESTMENT: DOES FIRM ORGANIZATION MATTER?
}

\author{
Vojislav Maksimovic \\ Gordon Phillips \\ Working Paper 12297 \\ http://www.nber.org/papers/w12297
NATIONAL BUREAU OF ECONOMIC RESEARCH 1050 Massachusetts Avenue
Cambridge, MA 02138
June 2006

University of Maryland and University of Maryland and NBER respectively. Maksimovic can be reached atvmax@ rhsmith.umd.edu and Phillips can be reached at gphillips@ rhsmith.umd.edu. This research was supported by the NSF. We would like to thank Mike Lemmon, Harold Mulherin, Sheri Tice, Bernie Yeung, CES staff and seminar participants at the American Finance Association meetings, Duke-UNC corporate finance conference, Financial Economics and Accounting conference at USC, 2005 Frontiers in Finance Conference, George Washington, HKUST, Minnesota, NYU, Pittsburg, Tanaka School, Texas, UBC, UCLA and Wharton. The research in this paper was conducted while the authors were Special Sworn Status researchers of the U.S. Census Bureau at the Center for Economic Studies. Research results and conclusions expressed are those of the authors and do not necessarily reflect the views of the Census Bureau. This paper has been screened to insure that no confidential data are revealed. The views expressed herein are those of the author(s) and do not necessarily reflect the views of the National Bureau of Economic Research.

(C2006 by Vojislav Maksimovic and Gordon Phillips. All rights reserved. Short sections of text, not to exceed two paragraphs, may be quoted without explicit permission provided that full credit, including (C) notice, is given to the source. 
The Industry Life Cycle and Acquisitions and Investment: Does Firm Organization Matter? Vojislav Maksimovic and Gordon Phillips

NBER Working Paper No. 12297

June 2006

JEL No. G0, G2, G3

\begin{abstract}
We examine the effect of financial dependence on acquisition and investment within existing industries by single-segment and conglomerate firms for industries undergoing different long run changes in industry conditions. Conglomerates and single-segment firms differ more in rates of within-industry acquisitions than in capital expenditure rates, which are similar across organizational type. In particular, 36 percent of within-industry growth by conglomerate firms in growth industries is from intra-industry acquisitions, compared to nine percent for single segment firms. Financial dependence, a deficit in a segment's internal financing, decreases the likelihood of within-industry acquisitions and opening new plants, especially for single-segment firms. These effects are mitigated for conglomerates in growth industries. The findings persist after controlling for firm size and segment productivity. Acquisitions lead to increased efficiency as plants acquired by conglomerate firms in growth industries increase in productivity post acquisition. The results are consistent with the comparative advantages of different firm organizations differing across long-run industry conditions.
\end{abstract}

Vojislav Maksimovic

Robert H. Smith School of Business

University of Maryland

College Park, MD 20742

vmax@rhsmith.umd.edu

Gordon M. Phillips

R.H. Smith School of Management

Van Munching Hall

University of Maryland

College Park, MD 20742

and NBER

gphillips@rhsmith.umd.edu 


\section{The Industry Life Cycle, Acquisitions and Investment: Does Firm Organization Matter?}

\section{Introduction}

An influential body of research has argued that industries go through life-cycle stages and that these stages are characterized by marked differences in investment and restructuring activity (Gort and Klepper (1982), Jovanovic (1982), Klepper and Grady (1990), Klepper (1996)). The evidence suggests that changes in the number of firms in an industry occur at times of transition in an industry's life cycle when the competitive advantage among producers is changing. However it is not known whether and how firm organization is associated with firm performance for industries that experience different changes in long-run conditions.

In this paper we examine whether long-term changes in industry conditions affect investment by singleindustry firms and divisions of conglomerate (multi-segment) firms differently. We focus on two factors that have been identified in the literature as giving multi-division firms an advantage in some competitive environments: access to internal capital markets and the ability to restructure stemming from a greater propensity to participate in the market for mergers and acquisitions. Specifically we ask:

- Does firm organization affect capital intra-industry acquisitions, plant births and deaths?

- Does the effect of organizational structure on firms' investment decisions depend on long-run industry conditions?

- Do differences in firm organization and industry conditions affect whether firms' investment decisions depend on shortfalls in cash flows from operations?

In studying firm organization, we distinguish between single-segment firms and conglomerate firms operating in multiple industries. These two types of firms are likely to have different access to financial resources (public markets and internal capital markets) and different types of monitoring (within firm hierarchies versus monitoring by external providers of capital). Moreover, the categorization builds on previous research that has established the importance of a division's position within its firm on its investment policy, efficiency, extent of internal monitoring, and access to internal capital markets. ${ }^{1}$

\footnotetext{
${ }^{1}$ Early authors include Lang and Stulz (1994) and Berger and Ofek (1995). We discuss the other papers in this literature that are related to this paper in Section 2.
} 
We classify industries into four different long-run categories: (1.) Growth industries in which the long-run industry shipments and the long-run number of firms are increasing and with changes for each of these factors both above the median industry change, (2.) Consolidating industries in which the change in the long-run shipments is above the median industry change but the change in the number of firms is below the median. (3.) Technological change industries in which the change in long-run demand is below the median industry change but the change in the number of firms is above, (4.) Declining industries in which the change in long-run demand and the long-run number of firms are both below the median industry change. The industry categories differ in the amount of restructuring (closings and acquisitions of business segments) and growth opportunities.

We find the within-industry acquisition behavior of conglomerate segments differs sharply from that of single-segment firms, even controlling for the productivity, public firm status, and the size of the purchaser. Segments of conglomerate firms are two to three times more likely to acquire plants within their existing industries than are single-segment firms. In particular, 36 percent of within-industry growth by conglomerate firms in growth industries is from intra-industry acquisitions compared to nine percent for single-segment firms. Acquisition rates also significantly differ across long-run industry conditions. Within-industry acquisitions by conglomerate segments in Growth industries represent a much higher percentage (ten percentage points higher) of total firm growth than acquisitions in Declining industries. In contrast to these findings, capital expenditures, which are typically the focus the prior research, vary less across organizational types and industry conditions.

We examine whether the differences in within-industry acquisition rates and investment by different types of firm organizations are related to financial dependence. We define as financially dependent those business segments (single-segment firms or segments of conglomerates) that spend more than their cash flow from operations on capital expenditures. ${ }^{2}$ We test whether the effect of financial dependence on acquisitions and investment differs for conglomerates and single-segment firms. We control for the endogeneity of organizational form and financial dependence. To control for potential endogeneity between capital expenditures and realized the cash flow from operations, in our empirical tests we examine how segments respond to predicted financial dependence rather than observed financial dependence.

We find financially dependent segments tend to fall into two categories: segments that are less productive compared to other segments in their industries and very productive segments in high growth industries. $^{3}$ We have three major findings that show how financial dependence and organizational form

\footnotetext{
${ }^{2}$ Thus, a segment that has an internal financial deficit in a year must rely on cash flows from outside the segment or on the liquidation of its assets to fund capital expenditures at the plants it owns.

${ }^{3}$ The term productive is defined below and refers to firms ability to produce revenue from inputs at the segment level.
} 
affect firm acquisition and investment over different long-run industry conditions:

First, we find that predicted financial dependence affects plant acquisitions and investment by conglomerate segments and single-segment firms differently. Financial dependence has a negative effect on capital expenditures and the probability of acquisitions. In Growth and Consolidation industries, conglomerate firms have a positive offsetting effect on within-industry acquisitions. ${ }^{4}$

Second, we show that the effects of firm organization on reducing financial dependence in Growth industries are concentrated in conglomerate firms' most productive segments. For conglomerate firms' most productive segments, financial dependence has only a limited effect on within-industry acquisitions. Moreover, in Growth industries, business segments of conglomerates have a significantly higher probability of acquiring plants within existing industries if the conglomerate also has a less productive main division in a declining industry. We also find that plants acquired by conglomerate firms - in particular in Growth industries - significantly increase in productivity post-acquisition. These results are consistent with models that stress the benefits of conglomerate form for the firms that adopt it, such Stein's (1997) model of the benefits of internal capital markets and the predictions about the efficient reallocations of assets within conglomerate firms in Maksimovic and Phillips (2002). These results are not consistent with models that predict subsidization of poorly performing divisions or divisions with poor growth prospects. The results are also not consistent with agency or empire building models that predict inefficient expansion.

Third, we also find large differences in the effect of organizational form on plant birth and exit across industry categories. In Growth industries, a segment's predicted financial deficit reduces the probability that a single-segment firm will open a new plant, while this effect is mitigated for conglomerate firms. However, we do not find similar effects on plant births in declining industries.

We find that plant exit differs across industry categories. Conglomerate firms are the least likely to close plants when their current segment is predicted to have a financial deficit in Declining industries. In Growth industries the relation between predicted financial dependence and plant exit is similar for conglomerate and single-segment firms - in contrast to the positive effect of conglomerate firms on acquisitions and plant birth.

These findings of decreased financial dependence for conglomerate firm acquisitions and plant births are consistent with conglomerates having experience in allocating resources and integrating operations.

It does not necessarily mean that conglomerate firms sell at a premium or discount in the market relative to single-segment firms.

${ }^{4}$ Results in an earlier working paper version of this paper also show that the effect of conglomerate firm status was robust to whether the firm was publicly traded. Public firm status did have an additional positive effect on mitigating the effect of financial dependence on acquisitions by public firms in Growth industries. However, this effect was much smaller in magnitude than the effect of conglomerate firm status. 
This positive benefit of internal capital markets is the highest for conglomerate firms in Growth industries - where the value of reallocating assets is likely to be the highest.

There are several key differences between our approach and the existing literature on investment and internal capital markets. First, we relate the firm's investment and financing needs to long-run changes in industry conditions. We show that long-run industry conditions are of primary importance to understanding the impact of organizational form on acquisitions and plant opening decisions. Second, the existing literature, with the exception of Maksimovic and Phillips (2001) and Schoar (2002), has examined the relation between capital expenditures and firm organization. We define investment more generally than the existing literature to encompass acquisitions of plants and assets. Thus, we can examine whether firm organization affects investment through acquisition and plant openings differently than regular investment. Since acquisitions require extensive organizational skill in integrating operations while capital expenditures represent decisions to existing operations, we examine whether the effects of organizational form are greater for acquisitions than capital expenditures at existing plants. ${ }^{5}$ Third, we are also able to obtain direct estimates of the productivity of each business unit, whether it is independent or part of a larger firm. Thus, we can determine whether the relation between firms' investment and their organizational structure depends on their productivity and we can examine ex post changes in underlying productivity of transacted assets.

We use data from the Longitudinal Research Database (LRD), maintained by the Center for Economic Studies at the Bureau of the Census. The LRD database contains detailed plant-level data for manufacturing plants. There are several advantages to this database: First, it covers both public and private firms in manufacturing industries. Second, coverage is at the plant level, and output is assigned by plants at the four-digit SIC code level. Thus, firms that produce under multiple SIC codes are not assigned to just one industry. Third, plant-level coverage means that we can track plants even as they change owners. The database contains a plant-level code that identifies when plants change ownership. These features are key to our study as they allow us to identify plants that have changed hands from year-to-year.

The rest of the paper is organized as follows. Section two describes the prior literature and why firm organization may have a differential impact over the industry life cycle. Section three introduces our methodology and Section four describes the data. The results are discussed in Section five. Section six concludes.

\footnotetext{
${ }^{5} \mathrm{GE}$, for example, has an extensive staff whose job function is to evaluate acquisitions.
} 


\section{Industry Conditions and Firm Organization}

Studies of industry evolution, by Gort and Klepper (1982) and Klepper and Grady (1990) among others, show that many industries go through life-cycle stages. These stages are characterized by differences in the growth rates of the industry and by dramatic changes in the numbers of producers in the industry. As the nature of competition and the comparative advantage of firms may shift across stages, many industries undergo periods of intensified competition and consolidation when many, perhaps the majority, of the producers are weeded out. Firm strategies that work in times of expansion, such as preemptively acquiring large capital intensive plants, may lead to a competitive disadvantage in decline (Ghemawat (1984), Ghemawat and Nalebuff (1985)). Thus these articles emphasize the importance of industry conditions on firms survival, and by extension on their capital budgeting decisions.

To examine the relation between the number of producers and industry growth, we first present some exploratory evidence on long-run industry conditions using Census Bureau data. We classify industries using Census Bureau data for the years 1972 and 1997. These years are used because they span 25 years of industry experience and are census years covering all firms. In Figure 1, we classify industries according to the growth in the real value of shipments. ${ }^{6}$ We examine changes in the number of firms for different long-run changes in demand, using the change in the real value (1982 dollars) of shipments by three-digit SIC code. We split industries by the highest and lowest quartiles of real value of firm shipment growth and graph the long-run changes in the number of firms. In our subsequent tests, we further split these industries by the long-run change in the number of producers into "Declining" and "Technological Change" industries for contracting industries and "Growth" and "Consolidation" industries for growing industries.
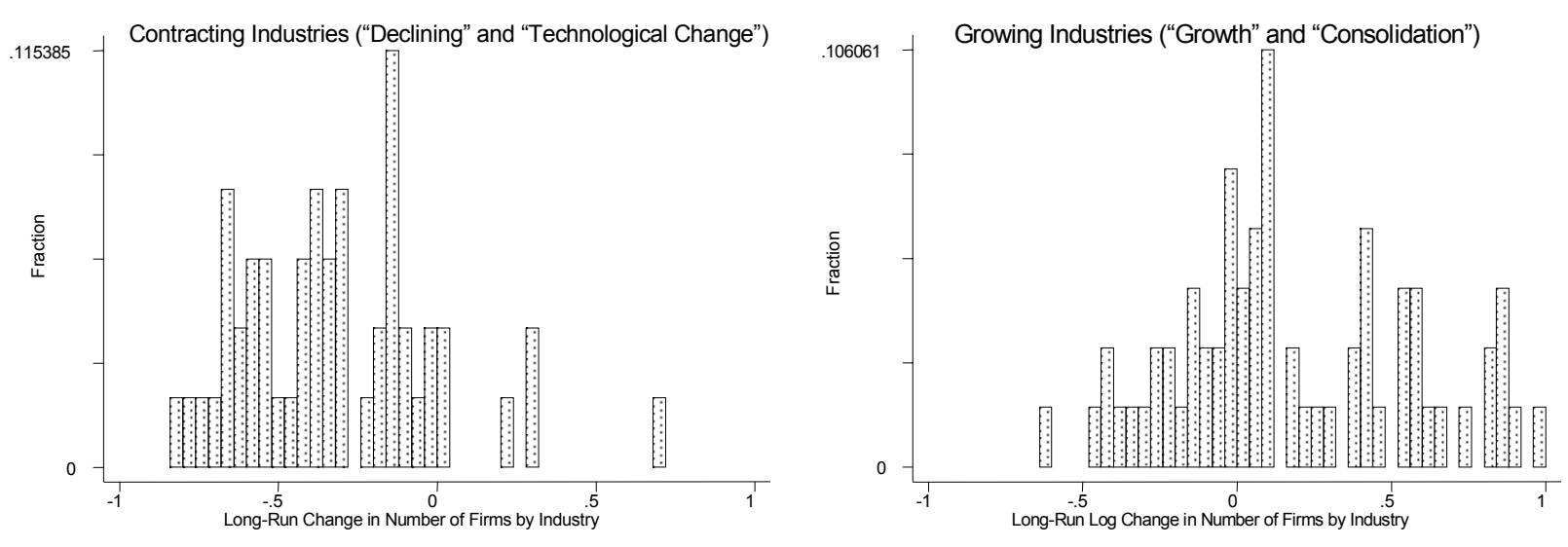

Figure 1

\footnotetext{
${ }^{6}$ We later discuss results using classifications based on 10-year intervals.
} 
The histograms show that in growing industries it is not uncommon to see a net increase of $30 \%$ in the number of producers and also for some industries a decline in the number of producers over the sample period. Whereas in contracting industries a $30 \%$ decrease is common.

The fact that the number of firms can decrease even in a growing industry, suggest that some firms may not possess the resources and / or skills necessary to survive. The resources and skills a firm requires to prosper in these different types of industries are likely to differ. In a growing industry, new producers are entering at high rates. Given that entrants are often high cost producers (Jovanovic (1982)), established firms in this industry type are less likely to face hard competition. Success in this type of industry is likely to depend on the ability to marshal resources to take advantage of growth opportunities. In a consolidating industry, the shipments are also growing rapidly but the competitive pressure is likely to be stronger. In these industries new producers are less likely to be entering and some existing producers might be forced out. We would expect that competitive advantages from belonging to a larger organization is likely to be most valuable in a fast growing consolidating industry.

Numerous studies suggest that the firm's organizational structure affects the way it invests, grows, and sells assets. Conglomerates have internal capital markets that can transfer capital across industries and may have better access to external capital markets than would be available to their constituent divisions if they had remained independent (Bolton and Scharfstein (1991), Khanna and Tice (2001), Stein (1997)). In particular, Stein (1997) models how conglomerate firms can efficiently transfer resources from unprofitable to profitable projects. Moreover, as Peyer (2001) shows empirically, conglomerates have superior ability to obtain external financing, giving divisions of conglomerates a competitive advantage when internally generated funds are not sufficient to finance desired investment. Thus, we would expect the investment by segments of conglomerates to be less affected by the level of internal financing than equivalent single segment firms.

The effect of conglomerate structure on investment need not be benign. One strand of the literature posits that the firm's investment policy is driven by opportunistic agents (usually the managers or the owners of a subset of the firm's securities), who attempt to distort the policy for their private benefit (see, Jensen and Meckling (1976) and Jensen (1986)). Thus, for example, managers may have a private benefit from investment in capacity (Jensen (1986) and Matsusaka and Nanda (2001)). Opportunistic behavior by agents may cause the firms to misallocate resources across industry segments. These possibilities are suggested by Lamont (1997), Shin and Stulz (1998), Rajan, Servaes and Zingales (2000), and Scharfstein and Stein (2000).

More generally, organizational form may be endogenously determined by a firm's expertise and its 
ability to exploit opportunities as argued by Campa and Kedia (2003), Maksimovic and Phillips (2002) and Villalonga (2004). Maksimovic and Phillips (2002) argue that conglomerates differ from single-segment firms because their organizational skills are not industry specific and that because of this they find it optimal to operate in several industries. In their model firm size and scope of operations adjust to economize on the firms' organizational talent. In this view as industries experience demand and technology shocks, firms' comparative advantage shifts. Conglomerates and single-industry firms shifts and firms adjust by building, acquiring or closing plants to maximize value. ${ }^{7}$. Because their model predicts a positive correlation between conglomerates' divisions size and productivity, the adjustments to shocks may depend on the relative size of a division within the conglomerate.

The tasks performed by a head office of a conglomerate are likely to differ across industry types. In Growth industries the head office of a multi-segment firm is faced with managing and providing resources for increases in capacity. In Declining industries the focus is likely to be on optimally shrinking operations and reallocating resources to other segments. In Technological Change industries firms have to adapt to increasing competition from new entrants in industries with slowly growing or declining shipments, while in Consolidation industries the decision is whether to remain in the industry. Since the nature of these tasks involves a different mixture of monitoring, winner picking, and financing, the comparative advantage of internal capital markets relative to public markets may differ across these long-run industry conditions.

In our tests we first examine the extent of differences the extent to which conglomerates mitigate the effects of resource constraints across these types of industries. The above discussion suggests that the effects of conglomerate status should be stronger in growing industries. Consider a growth industry in which firms encounter repeated expansion opportunities. Much of the value of such firms consists of unexploited, and therefore intangible growth opportunities. Corporate finance theory suggests that such firms are most likely to incur agency and asymmetric information costs when obtaining external finance (e.g., Myers (1977), Myers and Majluf (1984)). Internal capital markets are thus most likely to be of value in segments in growing industries. ${ }^{8}$ Thus, the first hypothesis that we investigate is the following:

H1: The effects of conglomerate status on mitigating the effects of financial dependence are greater in growing industries.

Maksimovic and Phillips (2002) show that conglomerate segments reallocate resources from less productive divisions to more productivity divisions when positive demand shocks are realized. Investment

\footnotetext{
${ }^{7}$ While not focusing on the industry life cycle, Bernardo and Chowdhry (2002) model how differential skills and opportunities over the firm's life endogenously causes a conglomerate discount given that as the firm matures it exercises its growth options.

${ }^{8}$ See, for example, Fluck and Lynch (1999).
} 
decisions by conglomerate firms in one industry may creates opportunity costs for investments in other industries in which they operate. Thus segments' investment decisions depend on the relative demand growth across industries. In our context, we hypothesize that conglomerate segments are more likely to exploit investment opportunities in growth industries if their other segments are in declining industries. This prediction is summarized in the following hypothesis:

H2: The effects of conglomerate status on mitigating the effects of financial dependence are greater in growing industries when conglomerate firms have productive segments in growing industries and other large divisions in declining industries.

Conglomerates operating across multiple industries have experience in allocating resources and integrating operations. Since acquisitions require extensive organizational skill in integrating operations, while capital expenditures typically represent incremental additions to existing operations, we would expect that differences in organizational form affect acquisitions more than capital expenditures at existing plants. In particular, conglomerates' ability to integrate different business units and allocate capital can increase the payoff to providing capital for acquisitions to segments of conglomerate firms compared to single-segment firms, while capital expenditures may involve similar decisions and skills for both conglomerate and singlesegment firms. We test whether conglomerates and single-segment firms that have a financial deficit allocate funds for acquisitions and capital expenditures at existing plants differently. We thus test the following hypothesis:

H3: The effects of organizational form and financial dependence are greater for acquisitions than for capital expenditures.

The effect of financial dependence on conglomerate segments and single-segment firms may differ because conglomerates efficiently provide resources to segments with insufficient internal resources that permit them to make value increasing acquisitions. However, it is also possible that conglomerate segments overinvest in acquisitions, perhaps due to agency reasons. While we cannot measure the private value created by acquisitions, which depends on the price paid, we can examine the subsequent changes in the acquired assets' productivity. Increases in productivity are consistent with the hypothesis that the acquisitions are economically efficient. We would expect these effects to be particularly important in growing industries. We test these predictions in the following hypothesis:

H4: Acquisitions by conglomerate firms result in increases in productivity of acquired segments. The increases in productivity are greatest in growth industries. 
Organizational form and financial dependence may also affect other capital budgeting decisions. We also examine how firms' decisions to close plants and to build new plants are affected by financial dependence and organizational form across industry conditions.

\section{Data, Long-Run Industry Conditions and Variable Construction}

In this section we describe the data, how we classify long-run industry conditions and how we calculate the variables used to test our hypotheses. The primary dependent variables we investigate are a firm's within-industry acquisitions of other plants and its segment-level capital expenditures. We also examine plant births and exits. Our first dependent variable, within-industry acquisition, takes on the value of one at the segment level if the conglomerate segment or stand-alone firm purchases one or more plants in that existing industry, and the value of zero otherwise. Our second measure, capital expenditures, measures plant-level capital expenditures at the plants owned by each firm at the beginning of each year and not sold during the year.

The primary independent variables we use are segment and plant productivity, the long-run change in aggregate industry conditions, and predicted financial dependence and organizational structure.

\subsection{Data}

We use data from the Longitudinal Research Database (LRD), maintained by the Center for Economic Studies at the Bureau of the Census. The LRD database contains detailed plant-level data on the value of shipments produced by each plant, investments broken down by equipment and buildings, and the number of employees. ${ }^{9}$

The LRD tracks approximately 50,000 manufacturing plants every year in the Annual Survey of Manufactures (ASM). The ASM covers all plants with more than 250 employees. Smaller plants are randomly selected every fifth year to complete a rotating five-year panel. Note that while the annual data is called the Annual Survey of Manufactures, reporting is not voluntary for large plants and is not voluntary once a smaller firm is selected to participate. All data has to be reported to the government by law and fines are levied for misreporting.

The data we use covers the period 1974 to 2000. To be in our sample, firms must have manufacturing operations producing products in SIC codes 2000-3999. Since we construct measures of productivity (described in section 3.3) using 5 years of data, our regressions cover the period 1979-2000. We require

\footnotetext{
${ }^{9}$ For a more detailed description of the Longitudinal Research Database (LRD) see McGuckin and Pascoe (1988) and also Maksimovic and Phillips (2002).
} 
each plant to have a minimum of three years of data. For each firm, we also exclude all its plants in an industry (at the three-digit SIC code) if the firm's total value of shipments in the industry is less than $\$ 1$ million in real 1982 dollars.

The database also identifies plants that change ownership. For ownership change we rely on this identification which was available for all years except 1978 (for an unknown reason coverage codes did not identify ownership change in this year). Plant birth and death were identified by John Haltiwanger using payroll records from the Longitudinal Business Database. ${ }^{10}$

To obtain a measure of organizational structure, we aggregate each firm's plant-level data into firm industry segments at the three-digit SIC code. We call these industry firm-level portfolios of plants "segments." Segments, defined this way, capture all the plant-level operations of a firm in an industry. ${ }^{11}$ We classify firms as single segment or multiple segment, based on the three-digit SIC code. We classify a firm as a multi-segment firm if it produces more than 10 percent of its sales in a second SIC code outside its principal three-digit SIC code. Using the 10 percent cut-off facilitates comparison with previous studies as 10 percent is the cut-off that public firms report. For multiple-segment firms, we also classify each segment as either a main segment or a peripheral segment. Main segments are segments whose value of shipments is at least $25 \%$ of the firm's total shipments. Given we calculate growth rates and also divide capital expenditures by lagged capital stock, we also lose the initial year a firm or firm segment enters the database. We also lose observations that are non-contiguous.

We include a firm's lagged size and the lagged number of plants in the segment as control variables. We also include the industry capital intensity, calculated as the sum of all capital expenditures divided by the sum of all industry shipments. We industry and year adjust all capital expenditure and productivity data, subtracting out the industry-year averages.

\subsection{Long-run Industry Conditions}

We classify industries on the basis of exogenous shifts in their operating environments that may require different financial and organizational capabilities of firms, and that may therefore enable us to identify the advantages of different organizational forms.

Given the differences in industry conditions previously shown in Figure 1, we capture the stages in

\footnotetext{
${ }^{10}$ We thank John Haltiwanger for providing us with these linkages.

${ }^{11}$ The segments we construct do not correspond to those reported by COMPUSTAT. However, segment data reported by COMPUSTAT are subject to reporting biases. Firms have considerable flexibility in how they report segments as shown by Pacter (1993). Firms may also have strategic reasons for the specific segments they choose or choose not to report, as Hayes and Lundholm (1996) shows. Hyland (1999) finds that only 72 percent of firms that report under the FASB standards that they go from one segment to more than one segment actually increase their number of segments.
} 
an industry life cycle by classifying 3-digit SIC manufacturing industries into four categories using both shipments growth and changes in the number of firms. The first cut divides industries into those in which the growth of the real value of shipments during our sample period, 1972-1997 exceeds the median growth of all manufacturing industries and the into those in which the growth of shipments fell below the median. Many industries in the latter category experience an actual decline in shipments. Our second cut divides industries into those in which the growth of the number of producers exceeds the median growth in the number of producers for a manufacturing industry and those industries in which the number of producers is lower than the median, again for the 1972-1997 period.

We also classify industries using ten-year floating windows, thereby allowing an industry to switch between life-cycle classifications over time (for example, from growth to declining). We use Census year data for these industry classifications because an accurate count of the number of firms is available in these years. Census years are every five years beginning with 1972. To classify an industry in a particular year using floating windows, we use the census year following a particular year and calculate the change to that census year from the census 10 years prior. Thus for 1993 we would calculate the change in the real value of shipments from 1987 to 1997. We also examine subperiods, specifically the 1980s and 1990s and found no material differences versus the 10 year analysis that we report.

Table 1 presents summary statistics by industry category. The table shows that the industries in our four categories differ significantly. Over the period 1972-1997 real shipments increase by an average of $43 \%$ in Growth Industries and decrease by $42 \%$ in Declining industries. Real shipments in Consolidating industries change little (a two percent increase). Shipments fall by $28 \%$ in Technological Change industries. As expected, the number of producers increases $(+83.6 \%)$ in Growth industries and decreases $(-34.6 \%)$ in Declining industries. Technological Change and Consolidating industries present a contrast. Despite a large drop in real output, the number of producers in the former increases by $45 \%$. In the latter, despite a stationary output level, there is a drop of $10.2 \%$ in the number of producers.

We also present long-run statistics for the 5 industries surrounding the average change in each category to give a more detailed description of which industries are in each category. Declining industries include iron and steel foundries, rubber and plastics footwear. Technological Change industries include metalworking machinery and equipment. Consolidation industries include paper mills and carpet and rugs. Growth industries include plastics, drugs and communications equipment.

\section{Insert Table 1 here}

In a declining industry both the number of firms and real shipments are growing more slowly than in 
a median industry. In many such industries the number of producers is falling and firms face the task of managing decline or optimally exiting. Cash flow may be low or negative and firms belonging to a conglomerate may be able to use its greater resources to obtain a competitive advantage. By examining differences in investment and acquisition activity of conglomerates and single-segment firms in these industries we can tell whether conglomerates shift resources away from industries with declining shipments.

Real shipments are also declining or growing slowly in Technological Change industries. However, the high rate of growth of new producers in those industries implies that there exist growth opportunities. Thus, by comparing the differences in investment patterns of conglomerates and single-segment firms in Declining and Technological Change industries we can examine whether conglomerate firms' response to decline in shipments depends on the existence of growth opportunities in an industry.

\subsection{Variable Construction: Financial Dependence and Productivity}

\section{A. Financial Dependence}

To obtain a measure of the extent to which stand-alone firms and conglomerate segments can finance their investment internally we define a segment to be financially dependent (independent) in particular year if the sum of the capital expenditures reported by all its plants exceeds (is less than) the total cash flow reported by these same plants. Cash flow is defined as the gross margin adjusted for inventory changes. A conglomerate segment or stand-alone firm that is financially independent is able to fund its plant-level capital expenditures directly from cash flow, without obtaining resources from head-office, other divisions, or from the financial markets.

To control for endogeneity, we first predict financial dependence and use the predicted financial dependence in our regressions. Our dependent variable takes on the value one if a segment is classified as financially dependent, and zero otherwise. For each segment in each year, predicted financial deficit is estimated using by regressing actual financial dependence on industry and firm-level variables that capture a segment's anticipated need for additional financing beyond that produced via that segment's internal cash flow.

In the regressions, our independent variables are the change in industry real shipments, lagged industry profitability measured by industry value added divided by industry shipments, industry capital intensity,

lagged segment-level productivity (fixed effect from a production function) estimated using five years of lagged data from the segment's industry, and the log of firm size.

Table 2 shows that a segment's cash flows depend on industry characteristics, in particular shipmentgrowth. To capture industry-level differences we include several control variables. To control for potential 
growth in the industry we use the change in industry shipments. To capture the amount of internal cash available to a segment we use industry value added, the difference between gross sales of the industry and the cost of materials, labor and energy used in production, divided by industry sales. To control for industry specific use of large amounts of fixed assets, we use industry capital intensity, the sum of industry capital expenditures divided by industry sales. The industry value added and industry capital intensity measures are computed annually. All segment- and industry-level variables are at the three-digit SIC code level. We include lagged segment productivity and segment productivity squared in the specification to allow for the possibility that highly productive firms invest more than their cash flows.

Our measure of predicted financial dependence is thus the predicted probability a segment will have investment greater than the segment's internal cash flow controlling for industry-level growth, internal cash flows and capital intensity, and firm-level productivity and size. The predicted financial dependence is then used to examine how the relation between investment and predicted financial dependence is affected by its ownership status (conglomerate or stand-alone), size, productivity and industry type. ${ }^{12}$

\section{B. Productivity of Industry Segments}

We calculate productivity for all firm segments at the plant level and aggregate this data into segments using weighted averages. Our primary measure of performance is total factor productivity (TFP). TFP takes the actual amount of output a plant produces with a given amount of inputs and compares it to a predicted amount of output. "Predicted output" is what the plant is expected to have produced, given the amount of inputs it used. A plant that produces more than the predicted amount of output has a greaterthan-average productivity. This measure does not impose the restrictions of constant returns to scale and constant elasticity of scale that a "dollar in, dollar out" cash flow measure requires. For robustness and comparability with prior studies, we also explore how segment growth is related to segment operating margin, both of the segment in question and of the conglomerates other segments. However, this operating margin differs from a typical cash flow number because our plant-level data does not measure indirect segmental level costs, such as advertising and research and development

To calculate a plant's predicted output, we assume that the plants in each industry have a translog production function. This functional form is a second-degree approximation to any arbitrary production function, and therefore takes into account interactions between inputs. In estimating the production function we use the last five years of data for each plant - thus the first year of our data for which we have calculated productivity is 1979 . For each industry we estimate this production function using an

\footnotetext{
${ }^{12} \mathrm{~A}$ division can be public and also be part of a conglomerate. Our specifications in the working paper version of this paper (available on SSRN) allow for this possibility.
} 
unbalanced panel with plant-level fixed effects. To estimate productivity, we take the translog production function and run a regression of log of the total value of shipments on the log of inputs, including crossproduct and squared terms:

$$
\ln Q_{i t}=A+f_{i}+\sum_{j=1}^{N} c_{j} \ln L_{j i t}+\sum_{j=1}^{N} \sum_{k=j}^{N} c_{j k} \ln L_{j i t} \ln L_{k i t},
$$

where $Q_{i t}$ represents output of plant $i$ in year $t$, and $L_{j i t}$ is the quantity of input $j$ used in production for plant $i$ for time period $t . A$ is a technology shift parameter, assumed to be constant by industry, $f_{i}$ is a plant-firm specific fixed effect (if a plant changes owners a new fixed effect is estimated. We leave off the firm subscript for tractability), and $c_{j}=\sum_{i=1}^{N} c_{j i}$ indexes returns-to-scale. We deflate for industry price at the four digit level.

We obtain two measures of plant-level TFP from equation (1). First we have a firm-industry segment fixed effect, $f_{i}$, which we use in the regression to predict segment financial dependence. The segment fixed effect captures persistent productivity effects, such as those arising from managerial quality (Griliches (1957) and Mundlak $(1961,1978))$. It also captures a segment's ability to price higher than the industry average. Second, we obtain a firm-plant residual that we aggregate up into segments using predicted output to construct a segment weighted productivity that we use in our regressions examining acquisitions, investment and plant birth.

In each case we standardize plant-level TFP by subtracting out industry average TFP in each year and dividing by the standard deviation of TFP for each industry. We standardize to control for differences in precision with which productivity is estimated within industries. This correction is analogous to a simple measurement error correction and is similar to the procedure used to produce standardized cumulative excess returns in event studies. ${ }^{13}$ In computing the segment-level productivity in our regressions we construct a weighted average of the individual plant productivities, with weights equal to the predicted output of each plant.

We also include other firm and segment-level variables in our regressions to provide additional control for unmeasured productivity differences and other factors, such as size, that can influence firm investment. We include the log of firm size and the number of plants operated in an industry segment at the beginning of the year. We define firm size as the total deflated (using industry price deflators) value of shipments in 1982 dollars.

In estimating the TFPs in our sample, we use data for over 1,000,000 plant years, and for approximately

\footnotetext{
${ }^{13}$ This standardization does not affect the results we report. The results have similar levels of significance when we do not standardize productivity in this manner.
} 
50,000 plants each year. In the productivity regression for each industry, we include three different types of inputs, capital, labor, and materials, as explanatory variables. All these data exist at the plant level. Our productivity calculations do not capture any headquarters or divisional level costs that are not reported at the plant-level (i.e. overhead, research and development). The ASM also does not state the actual quantity shipped by each plant, but shows only the value of shipments. We thus deflate the value of shipments by 1982 price deflators to get a real value of shipments. For all inputs and outputs measured in dollars, we adjust for inflation by using four-digit SIC deflator data from the Bartelsman and Gray (1994) database. Each input has to have a non-zero reported value. Kovenock and Phillips (1997) describe these inputs and the method for accounting for inflation and depreciation of capital stock in more detail.

\section{Results}

\subsection{Summary Statistics}

We first present summary statistics by both industry classification and also organization type. In particular we examine the relation between industry type and three variables of interest, cash flows, capital expenditures and plant acquisition.

\section{Insert Table 2 here}

Table 2 shows that the number of single-segment firms is far greater than the number of conglomerate firms. However, the number of segments operated by conglomerate firms and the percent of industry output produced by conglomerate firms is greater - with the exception of Growth industries - than that produced by single-segment firms. Interestingly, in Growth industries conglomerate firms operate 38 percent of the industry segments but produce a far greater percentage, 63.2 percent, of industry output. Thus, segment sizes of conglomerate firms relative to single segment firms are the largest in Growth industries.

The second panel of Table 2 shows that for segments as a whole the ratio of average annual cash flow to sales is positively related to the real rate of shipments growth. The ratio is highest in Growth industries at $7.30 \%$ and lowest in Declining industries at $4.13 \%$. The difference in these two ratios is statistically significant at the five percent level. Examining the cash flow statistics by organizational type, Table 2 shows that plants of conglomerate segments consistently realize substantially higher cash flows than those of stand-alone firms for all industry categories. Segment size and organizational type 
affect the differences in cash flows between segments of single- and multiple-segment firms. Large segments consistently realize substantially higher cash flows than small segments. The difference is approximately five to seven percentage points, and is particularly striking in Declining industries, where small segments are barely breaking even at the segment level. ${ }^{14}$ When we focus on large segments only, and vary the organizational form, the table shows that conglomerate segments consistently realize cash flows that are 1.5-3 percentage points higher than single-segment firms.

Next, we examine the ratio of average annual plant-level capital expenditures to lagged capital stock. This ratio is highest in Growth industries and lowest in Declining industries. The single-segment firms' capital expenditure to lagged capital stock ratio exceeds that of the mean segment of multi-segment firms in all industry categories. However, overall, the capital expenditure rates are similar across organizational forms.

The last block of numbers in Table 2 shows the percentage of total segment growth accounted for by within-segment acquisitions. The results show that proportion of firm growth accounted by acquisition is substantially higher for multiple-segment firms than for single-segment firms. In Declining industries, within-industry growth by acquisition for multiple-segment firms it is 26.07 percent, whereas it is only 5.31 percent of firm growth for single-segment firms. In Growth industries the difference is even larger. In Growth industries the within-industry growth via acquisition by multiple-segment firms is 36.08 percent, 25 percentage points more than proportion of growth of single-segment firms accounted by acquisition. Across industry categories, we see that within-industry growth via acquisition for multiple-segment firms in Growth industries is also 10 percentage points higher than the corresponding number for multiplesegment firms in Declining industries. ${ }^{15}$

These summary statistics show that differences in acquisition rates between multiple- and singlesegment firms are substantial. Capital expenditure rates are fairly stable across industries, segment size and firm organization, while acquisition rates vary sharply across different firm sizes and organizational forms. The literature on the relation between conglomerate cash flow and investment has focussed on whether conglomerates' capital expenditures are efficient or whether they are driven by financial constraints and agency issues. Although the data sources are not directly comparable because most previous studies use COMPUSTAT data, these initial results show that capital expenditures are not very different

\footnotetext{
${ }^{14}$ This suggests that models that predict early exit of larger producers in declining industries may be missing an important empirical difference between small and large segments.

${ }^{15}$ When we calculate the importance of acquisition using the numbers of plants purchased, we also find that conglomerate firms' acquisition rate in terms of number of plants purchased divided by the number of existhing plants is also two to three times greater than that of single-segment firms. In particular, the rate of acquisition by conglomerate firms in Consolidation and Growth industries is 3.1 and 2.6 times, respectively, the rate of single-segment firms.
} 
for single- and multiple-segment firms, and are in fact a higher percentage for single-segment firms. However, these summary statistics show that plant acquisition are sensitive to industry conditions, segment size and significantly greater for multiple-segment firms. The findings that effects of organizational form are greater for acquisitions than capital expenditures at existing plants are consistent with Hypothesis 3.

We next investigate segments' capital expenditures and plant acquisitions in a multivariate framework and examine how financial dependence of industry segments impacts acquisition and investment.

\subsection{Financial Dependence and Firm Organizational Status}

We begin our analysis of financial dependence in Table 3. Our goal is to analyze how financial dependence and industry factors affect a firm's investment and acquisition decisions. However, given that a firm segment's financial deficit may be endogenous, we first run a first-stage regression where we predict the financial dependence of a firm's segment at the three-digit SIC code. We use predicted dependence in our later regressions that examine investment and acquisitions.

In Table 3, we estimate a segment is predicted to be financially dependent using a panel logistic specification. A segment is classified as financially dependent, with financial dependence equal to 1, when its capital expenditures exceeds the segment's cash flow, and zero otherwise. We regress financial dependence on lagged firm and industry-level variables that capture its need for external (to the segment) financial capital.

\section{Insert Table 3 here}

Column 1 of Table 3 shows that a segment in a fast growing industry is less likely to be financially dependent than a segment in a slow growing industry. The table's results show that segments in capital intensive industries are more likely to be financially dependent. The relation between the probability of financial deficit and a segment's productivity is convex as there is a negative coefficient on productivity and a positive coefficient on productivity squared. Very high productivity thus increases the likelihood of financial dependence. This convexity causes a firm to be financially dependent at the 87th percentile of productivity, holding other characteristics at their median values. Lastly, large firms are less likely to be financially dependent.

In Table 2, Columns 2 and 3, we estimate this specification on two sub-samples: segments in industries with above median and below median change in real shipments over our long-run 25 year period. The sub-sample results are similar to those for the whole sample with several exceptions. The coefficient of the change in industry shipments changes from negative to positive (albeit insignificant) in growth 
industries. Second, the coefficient on lagged industry profitability is approximately one-third smaller in high-growth industries than in low-growth industries. Thus, while high-growth industries are more profitable, they demand even more capital to meet industry growth as profitability has a smaller impact on financial dependence in these industries. Third, the squared productivity term remains positive and highly significant in high-growth industries but is basically zero for slow-growth industries. Thus, in slow-growth industries there is no partial offsetting effect that makes highly productive segments more likely to be financially dependent. In these industries, productive segments are less likely to financially dependent than in high growth industries. These results are consistent with highly productive firm segments demanding more capital to invest in high-growth industries, thus increasing their likelihood of financial dependence.

To control for endogeneity of organizational status we conduct a similar analysis to examine the predicted decision to become a conglomerate. We use the predicted firm status in our subsequent regressions. ${ }^{16}$ In Table 4 we examine whether individual segments are more likely to be part of conglomerate firms. We undertake this analysis for two reasons. First, we recognize that firm status is endogenous and thus wish to use predicted firm status in subsequent regressions that examine investment and acquisitions. Second, the influence of industry factors on whether segments belong to conglomerate firms is of independent interest.

We estimate a logistic regression where the dependent variable is equal to one if the segment is part of a conglomerate firm in Column 1 of Table 4. Because we are exploring the role of financial dependence on the decision to be a conglomerate segment, our specification is similar to the one predicting financial dependence in Table 3. However, since our hypotheses predict that conglomerate segments have advantages in some industry categories we include long-run changes in industry shipments as a predictor. Since we do not split the sample by long-run changes in industry shipments, the inclusion of this variable is permitted.

\section{Insert Table 4 here}

The results show that in industries with high long-run growth industry shipments, segments are more likely to be part of a conglomerate firm. Short-run (annual) changes do not increase the probability that a segment belongs to a conglomerate firm. Industry capital intensity is a particularly important predictor of whether a segment belongs to a conglomerate firm, with a relative-odds ratio of 176 . Thus, a ten-percent increase in industry capital intensity increases the likelihood of a segment belonging to a conglomerate by 17.6 times. Productivity also has a significant impact on the status of a firm segment. Segments with

\footnotetext{
${ }^{16}$ In a previous draft, available from the authors, we used actual firm status in the regressions. The coefficients of the actual firm status indicator variables (not instrumented) were more significant for acquisitions and significant for plant exit. The significance of key interaction variables was similar in all cases. Thus, we view the results reported here as more conservative.
} 
low productivity and segments that are very highly productive are relatively more likely to be part of a conglomerate firm, yielding a U-shaped relation between productivity and conglomerate status.

\subsection{Plant Acquisitions}

\section{A. Financial Dependence and Acquisitions}

This section analyzes the effect of predicted financial dependence and firm organization on withinindustry plant acquisitions. Table 5 examines the effect of our different long-run industry categories using both 10 and 25 year windows. The 25 year window captures long run trends in the industry. The 10 year window allows an industry to switch categories over time. For any given year, the industry category for the 10 year window is calculated using the change in real value of industry shipments from surrounding census years. ${ }^{17}$

We estimate predicted financial dependence of segments using the specification presented in Table 3. We estimate the predicted probability of conglomerate status using the specification of Table 4 . As a measure of segment productivity we construct a weighted average of each plants productivity with weights equal to plant predicted shipments. We include the lagged number of firm plants in each segment as a control variable. ${ }^{18}$

\section{Insert Table 5 here}

In order to examine whether the effects are statistically different from each other for different industry categories, we form a triple-interaction variables. To form this variable we interact the predicted probability that a segment is part of a conglomerate with its predicted dependence and with the quadrant indicator variables. ${ }^{19}$

Table 5 reveals several patterns. First, for all industry categories, except for Declining industries in the 10-year window, single-segment firms that are predicted to be financially dependent have a lower

\footnotetext{
${ }^{17}$ We also estimate this specification using continuous measures of the changes in industry conditions - instead of the 4 separate quadrant indicators used here. We include the change in the number of firms and the change in industry shipments in separate specifications, over both 10- and 25-year periods to examine the effect of each of these long-run changes separately. The results are very similar and are avaible in a previous version of the paper.

${ }^{18}$ We also checked whether the results are robust to including firm size as a substitute for the number of firm plants. The results were similar and conclusions unaffected by this change.

${ }^{19}$ We also constructed a similar interaction variable for public firm status. The version of this paper available on SSRN shows that public firm status also offsets part of the negative effect of predicted dependence in Growth industries. The variable public interacted with predicted dependence is positive and significant in Growth industries for the 25 year period. However, this effect was much smaller than that for conglomerate firms thus we focus the paper on organizational form.
} 
probability of acquiring plants in their industry from other firms. Second, in all categories, except for Declining industries, this negative effect of financial dependence on acquisitions is offset for conglomerate firms. This offsetting effect is shown by the positive coefficient on the interaction of predicted financial dependence with conglomerate firm status and the quadrant indicator variable. The interaction effect is greatest in growing industries (Growth and Consolidating). The coefficient of the interaction variable for Growth industries is statistically greater than for the other industry categories for the 10-year window, and all industry categories except Consolidating industries for the 25-year window (chi-squared tests not reported). Thus these results support the prediction in Hypothesis 1 that the effects of organizational form on mitigating the effects of financial dependence is greatest in growing industries.

Lastly, given Lamont and Polk's (2002) finding that the diversity of conglomerate's operations across industries affects its value, we include a variable capturing a firm's diversity of opportunities. We include the standard deviation of industry growth across a conglomerate firm's segments. The regressions show that this variable is unrelated to the probability of a firm making acquisitions. ${ }^{20}$

Tables 6A further investigates the effects of organizational form in Growth industries. We examine Growth industries in detail because our previous results indicate that organizational form has a particularly large effect in these industries. Column 1 of this table examine the effect of conglomerate firms' status by itself when the interaction term between conglomerate status and predicted dependence is not included. In the third column we include a variable that measures the relative productivity of the firm's division in the growth industry relative to that of main divisions, if any, that the firm has in declining industries. This variable is calculated as the simple difference in productivity between these divisions. If a firm has no division in a declining industry. We use this variable to examine whether productive conglomerate segments if growth industries grow faster if the conglomerate has a less productive division in a declining industry, as predicted by Hypothesis 2. Finally, Columns 4 and 5 split the segments into high and low productivity subsamples. This enables us to see high and low productivity segments of conglomerates in growth industries have different investment patterns.

\section{Insert Table 6A here}

Column one of Table $6 \mathrm{~A}$ shows that conglomerate firm status positively is positively related to the

\footnotetext{
${ }^{20}$ Using the input-output matrix we also examined whether these results varied by whehter or not the conglomerate's divisions were in related versus unrelated industries. We found that the results for financial dependence were not affected much by whether the conglomerate segments are unrelated or related.
} 
rate of acquisitions. As shown in the second column, the coefficient on the interaction variable between predicted conglomerate status and the predicted financing deficit is also positive and significant. Columns three and five in Table 6A show that conglomerate segments in Growth industries have a significantly higher probability of acquiring plants if the conglomerate also has a less productive main division in a declining industry. These results show that multi-segment firms acquiring additional plants in their productive segments in growth industries and relaxing financial dependence for these segments. As predicted by Hypothesis 2, this effect is greater when conglomerate firms also have a division in a declining industry.

\section{B. Economic Significance of Our Results}

To investigate the economic significance of these effects, we compute the probability that a segment belonging to different subsamples of single-segment and multi-segment firms acquires a plant. For each subsample we use the median value of each variable and then vary the predicted probability that a segment is financially dependent from the 10th to the 90th percentile. We compute the probability that a segment makes an acquisition for different levels of the predicted probability of financial dependence.

\section{Insert Table 6B here}

Table $6 \mathrm{~B}$ reports the economic significance of our results. We report the probability of within-industry acquisitions for conglomerate and single-segment firms using the specification in Table 5A, column 2. We also report economic effects for the Declining industry quadrant using a similar specification for comparability. The table shows that multi-segment firms have substantially higher probabilities of making an acquisition than single-segment firms. Thus, for example, in Growth industries a conglomerate segment with the median levels of all variables for conglomerate segments has a $6.26 \%$ probability of making an acquisition in an any year, whereas the single-segment firm has a $0.57 \%$ probability of making an acquisition at the median levels of the variables for single-segment firms. As the probability of being financially constrained increases from the 10th percentile to the 90th percentile the probability of acquisitions increases for multi-segment firms but decreases for single-segment firms. Thus financially dependent single-segment firms are less likely to acquire plants, whereas financially dependent conglomerate segments are more likely to acquire plants. Given that financial dependence occurs when a segment's investment is high relative to its cash flow, this suggests that segments of conglomerate firms acquire plants when capital expenditures exceed segment cash flow, while single-segment firms have difficulty in making acquisitions when capital expenditures exceed cash flow. 
To investigate the causes of these differences in acquisition probabilities between single-segment firms and conglomerate segments we recompute the probability of acquisition for single-segment firms using the median values of the data from conglomerate segments and the coefficient estimates for single-firms. We obtain these probabilities by setting the conglomerate dummy and segment rank to zero. The computed probabilities are estimates of the probability that single-segment firms would have acquired plants if they had the median data values of the conglomerate firms in our sample. The estimates show that there a substantial proportion of the difference in estimated probabilities is explained by differences in characteristics of single-segment and conglomerate firms. Thus, in Growth Industries, the median single-segment firm would have had $4.22 \%$ probability of making an acquisition if it had the data from the median multi-segment firm (as opposed to the actual median single-segment firm, which has a $0.39 \%$ probability of acquisition). The difference between the median conglomerate segment's estimated $6.26 \%$ estimated probability of making an acquisition and the $4.55 \%$ probability the single-segment would have had if it had the median values of the data for a conglomerate firm can be attributed to differences in organizational form. The results show that organizational form makes a larger difference for segments predicted to be financially dependent than for segments not predicted to be financially dependent. Comparing across the first and last rows for Declining and Growth industries (comparing conglomerate segments to single-segments with the data from conglomerate segments), it is striking that organizational form makes a larger difference (almost twice as large) in Growth industries than in Declining industries.

In the third and fourth panels, we also spilt the data into high and low productivity segments and compute the predicted probability of an acquisition using the specifications in columns 5 and 6 of Table $6 \mathrm{~A}$. The results show that the previous effects of organizational form are higher for more productive segments of conglomerate firms. As shown in the third panel, the probability of a within-industry acquisition for multi-segment firms increases to $7.97 \%$ when predicted financial dependence is at the 90th percentile. This evidence is consistent with conglomerate firms helping acquire plants in productive business segments.

These results shows that within-industry acquisition probabilities depend on firm organizational form in several different ways. First, conglomerate firms do acquire more within their industries than single segment firms overall. Second, particularly in Growth industries, acquisition probabilities increase with predicted financial dependence for conglomerate firms' productivity segments, while they decrease with financial dependence for single-segment firms. This finding is consistent with conglomerate firms providing resources to segments with growth opportunities. Third, the acquisition probability of a conglomerate firm's most productive segments in growth industries increases when it has a division in a declining industry - a result that is consistent with the theoretical prediction in Stein (1997) and Maksimovic and 
Phillips (2002) and also with Boston Consulting Group's prescription for non-growth industries to help fund "shining stars." The results are not consistent with theories which predict that conglomerate firms subsidize their less-efficient divisions because of influence costs.

\section{Post-Acquisition Changes in Productivity}

To examine whether these acquisitions are associated with value creation, Table 7 presents the ex post changes in productivity for the acquired plants. We compute the changes in productivity over a four-year window. These changes in productivity are industry and year adjusted.

\section{Insert Table 7 here}

Table 7 shows that productivity changes for conglomerate acquisitions are significantly greater than zero in Technological Change and, in particular, in Growth industries. In all windows, -1 to $+1,+2,+3$ and +4 we find that industry-adjusted productivity significantly increases. In contrast, plants purchased by singlesegment firms in these industries either show no significant increase or a slight decrease in productivity.

In sum, growth by acquisition is greater for segments of firms that are organized as conglomerates. Predicted financial dependence reduces the probability that a single-segment firm grows by acquisition, but has a considerably smaller, if any, effect on conglomerate segments. Consistent with Hypothesis 4, plants acquired by conglomerate firms in Technological Change and Growth industries experience significant increases in productivity post-acquisition. These results are not consistent with agency theories that predict that conglomerates overexpand into industries without good growth prospects and in which they have little expertise.

Overall, the analysis suggests that acquisition activity of conglomerates is consistent with Stein's (1997) model of the benefits of internal capital markets and the predictions about the efficient reallocation of assets within conglomerate firms in Maksimovic and Phillips (2002). These results are not consistent with models that predict subsidization of poorly performing divisions or divisions with poor growth prospects. The results are also not consistent with agency or empire building models that predict expansion into industries without considering the ex post prospects and productivity in these industries.

\subsection{Capital Expenditures}

We next examine the impact of predicted financial dependence and organizational form on capital expenditures. To test the effect of financial dependence and organizational form on capital expenditures, we interact predicted conglomerate firm status with predicted financial dependence. In Table 8, we estimate our capital expenditures regression for the four different industry categories separately. Alternative 
specifications using industry interaction variables, as in Table 5A, give similar results.

\section{Insert Table 8 here}

Table 8 shows that the effects of financial dependence and conglomerate structure depend on industry categories. Predicted financial dependence negatively affects capital expenditures in all categories. However, the negative effect of financial dependence is greatest for single-segment firms than for conglomerate segments, as the interaction term, conglomerate status times predicted dependence, is positive and significant for all categories. We do find that this interaction term is significantly higher for Consolidation and Growth industries versus Declining and Technological Change categories.

Finally, the weighted average plant-level productivity of a segment is significantly related to investment in all industry categories. This finding contrasts with the case of acquisitions where the effect was only present in growth industries. The relation between a segment's productivity and its capital expenditures is more robust than the relation between its productivity and the probability of within-industry acquisitions.

As a robustness test, we also checked whether the same results hold when we consider only major investments by firms. Whited (2002) shows that peripheral divisions of conglomerates make large investments more frequently that similarly sized single-segment firms. We rerun the regressions taking as our dependent variable an indicator variables that takes the value 1 if the ratio of capital expenditures over lagged capital stock employed by the segment exceeds the 90th percentile of this variable, industry adjusted. These regressions are more likely to pick up major investments by smaller segments because large segments with many plants are more likely to be able to smooth their investment flows across time.

These unreported regressions show that our results are robust across all industry categories. In each case, single-segment firms not predicted to be financially dependent are most likely to invest the most, and single segment firms predicted to be financially dependent invest the least. The investment of conglomerate segments falls between these two levels, with those conglomerate segments predicted to be financially dependent investing less than financially independent segments. We also find that in every industry category the more productive firms have a higher probability of a major investment than the less productive firms.

Comparing these results for capital expenditures with the results for acquisitions (Table 5 and $6 \mathrm{~A}$ ), we find evidence consistent with Hypothesis 3, that the effect of conglomerate organization on acquisitions is stronger than it is on capital expenditures. This evidence is of interest since the study of capital expenditures has received the most attention by previous research. 


\subsection{New Plant Openings and Plant Exit}

We next examine the effect of predicted financial dependence and firm organization on new plant openings and plant exit over across our industry categories. For new plant openings, we aggregate a firm's plants up into three-digit industries to examine whether a particular firm-segment acquires an additional plant.

\section{Insert Table 9 here}

Table 9 shows that in Growth and Consolidating industries predicted financial dependence has a significant negative effect on plant openings of for single-segment firms. Conglomerate firms mitigate the effects of predicted financial dependence on new plant openings for their segments in Growth industries. Table 9 shows that the key conglomerate interaction variable only affects plant births in Growth industries and Consolidation industries. ${ }^{21}$ As expected, we also find that segments with a higher number of plants are more likely to open plants in all industry categories.

\section{Insert Table 10 here}

Table 10 examines plant exit over the different industry categories. We run these regressions at the plant level and assign the dependent variable equal to one if the plant exits in a given year and zero otherwise. Table 10 shows that the effect of predicted financial dependence on plant exit is insignificant in all categories except for Growth industries. The effect of conglomerate firm status is limited. Plants of conglomerate firms that belong to segments predicted to be financially dependent are less likely to close in Declining industries as shown by the interaction variable conglomerate*predicted dependence. In other industry categories this effect is insignificant. More efficient plants are also less likely to be closed down. Segment size affects closure in two ways. As the number of plants in a segment increases, closure probabilities increase. However bigger segments are less likely to be closed down, as shown by the coefficient on segment rank. ${ }^{22}$

Overall, the results for new plant openings and plant exit differ over our long-run industry categories. New plant openings and plant exit depend on firm organizational form in several different ways. First, in growth industries, conglomerate firms that are predicted to be financially dependent have a significantly higher probability of new plant openings compared to dependent single-segment firms. Second, the probability of new plant openings by private, single-segment firms are the most adversely affected by predicted

\footnotetext{
${ }^{21}$ Results in the working paper show that this effect was robust to including public firm status variable.

${ }^{22}$ Unpreported regressions show that public firms are more likely to close plants, significantly so in Consolidation and Growth industries. However the interaction effect of predicted public status with financial dependence was insignificant for all industry categories.
} 
financial dependence. Third, there is a more limited effect of conglomerate organizational form and financial dependence on plant exit. In declining industries, conglomerate firms are less likely to close plants of segments predicted to be financially dependent. However, this effect is insignificant in other industry categories. These results suggest that organizational form affects exit and plant openings differently, most likely because plant openings require significant resources, including the ability to integrate the new plant into existing operations, while plant exit does not. The results are consistent with Hypotheses 2 and 4 that conglomerate firms have skills in integrating new acquisitions and providing resources that affect large decisions like acquisitions and plant openings in productive industry segments.

\section{Conclusions}

A growing corporate finance literature examines how multi-industry firms allocate investment across divisions. This literature tacitly assumes industries do not differ much and that the relevant differences can be summarized by simple measures of investment opportunities. We argue that the competitive environment of an industry depends on changes in long-run industry conditions. Industries in different stages of their life cycle differ in the opportunities for profitable restructuring and in exploitable growth opportunities. These differences in the competitive environment have the potential to alter the comparative advantage of conglomerate multi-industry firms relative to single-industry firms. A comparative analysis of investment by segments of conglomerates and single-industry firms has to take these differences into account. To this end, we classify U.S. manufacturing industries into four different long-run industry categories based on the growth rates of real shipments and changes in the number of producers.

We find evidence that the effects of firm organization vary across these long-run industry changes. We have four major results that show the importance of long-run industry conditions.

First, in industries where shipments are growing, within-industry acquisitions and new plant openings are significantly affected by firm organizational form. Conglomerates' segments are much more likely to purchase a plant adding to their existing segments than are single-industry firms. By contrast, capital expenditure rates are fairly stable across industries, segment size and firm organization.

Second, examining acquired plants post-acquisition, we find that plants acquired by conglomerate firms in Technological Change and, in particular, in Growth industries significantly increase in productivity post-acquisition. 
Third, we find evidence that within-industry acquisition rates are higher for conglomerates in growth industries when their divisions have high relative productivity versus their divisions in declining industries. Since the conglomerate effect on acquisitions is stronger for segments of high productivity there does not appear to be subsidization of a conglomerate's less efficient segments.

Fourth, for new plant openings, we find that there is a significant positive effect of belonging to a conglomerate in growth industries. Conglomerate firms offset the effects of predicted financial dependence on new plant openings in growth industries. The effects on plant exit are more limited.

These findings are consistent with the existence of benefits of internal capital markets as argued by Stein (1997) and examined empirically by Khanna and Tice (2001) and Peyer (2001). The finding that the probability of an acquisition in growth industries increases for conglomerate firms which have high productivity segments in growing industries and substantial other segments in declining industries are consistent with the theoretical prediction in Maksimovic and Phillips (2002). These results are not consistent with models that predict subsidization of poorly performing divisions or divisions with poor growth prospects. The results are also not consistent with agency or empire building models that predict inefficient expansion into industries.

These findings have important implications for the literature on conglomerates' allocation of investment. This literature uses capital expenditures to proxy for investment by a segment. Thus, it leaves out plant acquisition, which is an important component of conglomerate firms' investment but is not an important component of single-industry firms' investment. We document large effects of organizational form on financial dependence on acquisitions and plant openings. The differences in these effects of firm organization are largest in growing industries. These effect of organizational form on financial dependence on acquisitions has not been previously identified and is even stronger than the usually studied relation between conglomerate status and capital expenditures.

Overall, these findings document important effects of firm organization that vary over long-run changes in industry conditions. The findings are consistent with conglomerate in growth industries providing resources that help business segments reduce or break the link between a segment's predicted financial dependence and its growth via acquisition and new plant opening decisions. 


\section{REFERENCES}

Bernardo, Antonio and Bhagwan Chowdhry, 2002, Resources, Real Options and Corporate Strategy, Journal of Financial Economics 63, 211-34.

Campa, Jose, and Simi Kedia, 2002, Explaining the Diversification Discount, Journal of Finance.

Chevalier, Judith, 2002, Why do firms undertake diversifying mergers? An examination of the investment policies of merging firms, Mimeo, University of Chicago.

Fluck, Z. and A. Lynch, 1999, Why Firms Merge and then Divest: A Theory of Financial Synergy, Journal of Business 72, 319-346.

Gertner, Robert H., David S. Scharfstein, Jeremy Stein, 1994, Internal versus External Capital Markets, Quarterly Journal of Economics, 109(4), 1211-30.

Ghemawat, Pankaj. "Capacity Expansion in the Titanium Dioxide Industry." The Journal of Industrial Economics 33, no. 2 (December 1984): 145-163.

_ _ and Barry Nalebuff. "Exit." The RAND Journal of Economics 16, no. 2 (summer 1985): 184-194

— , and Tarun Khanna. "The Nature of Diversified Business Groups: A Research Design and Two Case Studies." Harvard Business School Working Paper Series, No. 97-043, 1996

Gort, Michael and Steven Klepper, 1982, Time Paths in the Diffusion of Product Innovations, Economic Journal 92 1982: 630-653

Graham, John, Michael Lemmon, and Jack Wolf, 2002, Does Corporate Diversification Destroy Value?,Journal of Finance.

Jensen, Michael C., 1986, Agency costs of free cash flow, corporate finance, and takeovers, American Economic Review 76, 323-329.

Jovanovic, Boyan, 1982, Selection and the Evolution of Industry, Econometrica; 50(3), 649-70.

Jensen, Michael C., 1986, Agency costs of free cash flow, corporate finance, and takeovers, American Economic Review 76, 323-329.

Jensen, Michael C. and William Meckling, 1976, Theory of the Firm: Managerial Behavior, Agency Costs and Ownership Structure, Journal of Finance and Economics 3, 305-360.

John, Kose, and Eli Ofek, 1995, Asset sales and the increase in focus, Journal of Financial Economics $37,105-126$.

Kaplan, Steven N., and Michael Weisbach, 1992, The success of acquisitions: evidence from divestitures, The Journal of Finance 47, 107-138

Khanna, Naveen, and Sheri Tice, 2001, The Bright Side of Internal Capital Markets, Journal of Finance forthcoming.

Klepper, Steven and Elizabeth Grady, 1990, The evolution of new industries and the determinants of market structure. Rand Journal of Economics 21:24-44.

Klepper, Steven, 1996, Entry, exit, growth, and innovation over the product life cycle. American Economic Review 86:562-583.

— 1997, Capital structure and product market behavior: An examination of plant exit and investment behavior, Review of Financial Studies 10, 767-804.

Lamont, Owen, 1997, Cash Flow and Investment: Evidence from Internal Capital Markets, Journal of Finance, 52, 83-109.

Lamont, Owen. and Christopher Polk, 2002, "Does Diversification Destroy Value? Evidence From The Industry Shocks," Journal of Financial Economics 63, 51-77. 
Lichtenberg, Frank R., and Donald Siegel, 1992, Takeovers and corporate overhead, in Corporate Takeovers and Productivity, Frank R. Lichtenberg, ed.: (MIT Press, Cambridge, MA).

Lucas, Robert, 1978, On the size distribution of business firms, Bell Journal of Economics 9, 508-23.

Maksimovic, Vojislav, and Gordon Phillips, 1998, Asset Efficiency and the Reallocation Decisions of Bankrupt Firms, Journal of Finance.

—, 2001, The Market for Corporate Assets: Who Engages in Mergers and Asset Sales and are there Gains?, Journal of Finance.

— , 2002, Do Conglomerate Firms Allocate Resources Inefficiently Across Industries?, Journal of Finance.

Matsusaka, John G., and Vikram Nanda, 2001, Internal capital markets and corporate refocusing, Journal of Financial Intermediation.

Meyer, Bruce, 1990, Unemployment Insurance and Unemployment Spells, Econometrica 58(4): 757 - 782.

Minton, Bernadette and Karen Wruck, 2001, Financial Conservatism: Evidence on Capital Structure from Low Leverage Firms, Working paper Ohio State University.

Mitchell, Mark L., and Harold J. Mulherin, 1996, The impact of industry shocks on takeover and restructuring activity, Journal of Financial Economics 41:2, 193-229

Morck, Randall, Andrei Shleifer, and Robert W. Vishny, 1990, Do managerial objectives drive bad acquisitions, Journal of Finance 45, 31-48.

Opler Tim C., Sheridan Titman, 1994, Financial distress and corporate performance, Journal of Finance 49, No. 3, 1015-1040.

Opler, Tim C., René M. Stulz, Lee Pinkowitz and Rohan Williamson, 1999, The Determinants and Implications of Corporate Cash Holdings, Journal of Financial Economics 52, 3-46.

Peyer, Urs, 2001, Internal and External Capital Markets, Mimeo, University of North Carolina.

Rajan, Raghuram G., Henri Servaes and Luigi Zingales, 2000, The cost of diversity: The diversification discount and inefficient investment, Journal of Finance 55, 35-80.

Ravenscraft, David, and F.M. Scherer, 1987, Mergers, Sell-offs, and Economic Efficiency (Brookings Institution, Washington, D.C.).

Scharfstein, David S., and Jeremy C. Stein, 2000, The dark side of internal capital markets: divisional rent-seeking and inefficient investment, Journal of Finance 55, 2537-2564.

Schlingemann, Frederik, P., Rene M. Stulz, and Ralph A. Walkling, 2002, Asset liquidity and segment divestitures, Journal of Financial Economics.

Schoar, Antoinette, 2002, Effects of Corporate Diversification on Productivity, Journal of Finance, 57 2379-2403.

Shin, H. and Rene Stulz, 1998, Are Internal Capital Markets Efficient? Quarterly Journal of Economics $531-52$.

Shleifer, Andrei, and Robert W. Vishny, 1992, Liquidation values and debt capacity: A market equilibrium approach, Journal of Finance 47, 1343-1365.

Stein, Jeremy, 1997, Internal Capital Markets and the Competition for Corporate Resources, Journal of Finance 52, 111-33.

Villalonga, Belen, 2003, Diversification discount or premium? New evidence from BITS establishmentlevel data, Journal of Finance, forthcoming

Whited, Toni, 2001, Is inefficient investment the cause of the conglomerate discount?, Journal of Finance. 
Table 1

\section{Long-Run Industry Conditions}

Table presents summary statistics by long-run industry changes and organization over 25 years. Declining (technological change, consolidation, growth) industries are industries that have long-run change in the real value (PPI deflated) of industry shipments over 1972-1987 in the lowest (lowest, highest, highest) fiftieth percentile and the long-run change in the number of firms in the lowest (highest, lowest, highest) fiftieth percentile.

Industry Classification / SIC code
Long-run (25 year) Change in: Industry Shipments Number of Firms
All Declining Industries - Average Change

Industries surrounding the average change in shipments

332 Iron and Steel Foundaries

302 Rubber And Plastics Footwear

311 Leather Tanning And Finishing

271 Newspapers: Publishing and Printing

341 Metal Cans And Shipping Containers

All Technological Change Industries - Average Change

Industries surrounding the average change in shipments

281 Industrial Inorganic Chemicals

329 Abrasive, Asbestos, And Miscellaneous

354 Metalworking Machinery And Equipment

342 Cutlery, Handtools, And General Hardware

356 General Industrial Machinery And Equipment

All Consolidation Industries - Average Change

Industries surrounding the average change in shipments

228 Yarn And Thread Mills

203 Canned, Frozen, And Preserved Fruits, Vegetables

201 Meat Products

262 Paper Mills

227 Carpets And Rugs

All Growth Industries - Average Change

Industries surrounding the average change in shipments

282 Plastics Materials And Synthetic Resins

381 Search, Detection, Navigation, Guidance

283 Drugs

308 Plastic Products

366 Communications Equipment

$-41.95 \% \quad-34.64 \%$

$-52.56 \% \quad-25.79 \%$

$-47.35 \% \quad-37.25 \%$

$-47.15 \% \quad-47.88 \%$

$-41.88 \% \quad-40.48 \%$

$-37.22 \% \quad 1.42 \%$

$-28.41 \% \quad 44.96 \%$

$-30.53 \% \quad 54.09 \%$

$-28.59 \% \quad 41.46 \%$

$-25.92 \% \quad 44.60 \%$

$-22.55 \% \quad 28.93 \%$

$-17.73 \% \quad 54.00 \%$

$1.75 \% \quad-10.22 \%$

$-2.20 \% \quad-28.23 \%$

$-0.87 \% \quad-8.45 \%$

$4.90 \% \quad-26.62 \%$

$6.88 \% \quad-23.46 \%$

$15.97 \% \quad-15.72 \%$

$42.99 \% \quad 83.55 \%$

$17.24 \% \quad 61.43 \%$

$36.39 \% \quad 198.89 \%$

$61.89 \% \quad 123.85 \%$

$129.45 \% \quad 161.42 \%$

$202.02 \% \quad 90.84 \%$

All average changes are significantly different across industry categories. 
Table 2

\section{Investment, Acquisitions and Industry Conditions}

Table presents investment and acquisition statistics by long-run industry changes and organization over 25 years. Declining (technological change, consolidation, growth) industries are industries that have long-run change in the real value (PPI deflated) of industry shipments over 1972-1987 in the lowest (lowest, highest, highest) fiftieth percentile and the long-run change in the number of firms in the lowest (highest, lowest, highest) fiftieth percentile.

Industry classifications

\section{Declining}

Technological

Summary Statistics by Organizational Form

Number of firms: $\quad$ Single-segment firms

Multiple-segment firms

Average number of segments for multiple segment firn

Percent of total segments of multiple-segment firms

Percent of industry output produced by multiple-segment firms
Change
3,731

675

6.53

$54.16 \%$

$64.70 \%$
3,378

867

6.17
Consolidation

2,855

577

5.62

$53.18 \%$

$67.18 \%$
Growth
$69.18 \%$

$4.96 \%$

$6.72 \%$

$7.30 \%$

11,322

1,463

4.81

$38.33 \%$

$63.18 \%$

Average annual plant-level cash flow / sales

Plants of: All firms

Single-segment firms

Multiple-segment firms

Small firms

Large firms

Large single-segment firms

Large multi-segment firms

$\begin{array}{lcccc}4.13 \% & 4.96 \% & 6.72 \% & 7.30 \% & \mathrm{~d} \\ 3.65 \% & 3.11 \% & 5.54 \% & 5.61 \% & \mathrm{~d} \\ 5.35 \% & 7.87 \% & 9.76 \% & 10.43 \% & \mathrm{~d} \\ 0.53 \% & 1.76 \% & 2.60 \% & 3.71 \% & \mathrm{~d} \\ 7.69 \% & 8.13 \% & 10.82 \% & 10.87 \% & \mathrm{~d} \\ 7.48 \% & 6.59 \% & 9.90 \% & 9.26 \% & \mathrm{~d} \\ 8.02 \% & 9.49 \% & 12.17 \% & 12.56 \% & \mathrm{~d}\end{array}$

Average annual plant-level capital expenditures / lagged capital stock

Plants of: All firms

Single-segment firms

Multiple-segment firms

Small firms

Large firms
$16.93 \%$

$17.24 \%$

$16.17 \%$

$16.14 \%$

$17.29 \%$
$17.31 \%$

$18.10 \%$

$16.10 \%$

$17.33 \%$

$17.30 \%$
$17.59 \%$

$18.02 \%$

$16.49 \%$

$16.45 \%$

$18.03 \%$
$19.39 \%$

$20.09 \%$

$18.14 \%$

$18.88 \%$

$19.63 \%$

Percent of total shipments growth accounted

for by acquisitions

Single-segment firms

Multiple-segment firms

Small firms

Large firms

$5.31 \%$
$26.07 \%$
$15.95 \%$
$20.08 \%$

$7.42 \%$

$30.17 \%$

$21.25 \%$

$24.56 \%$

\section{$8.85 \%$}

$30.71 \%$

$20.30 \%$

$24.43 \%$
$9.05 \% \quad$ e

$36.08 \% \quad \mathrm{~d}$

$24.61 \% \quad$ d

$28.52 \% \quad \mathrm{~d}$

\footnotetext{
${ }^{\mathrm{d}, \mathrm{e}}$ Difference between Declining and Growth industries is significantly different from zero at the one-, five-percent level.
} 
Table 3: Financial Dependence

Panel logit regressions examining the probability a division of a firm will invest more than its divisional cash flow. Annual change in industry shipments is the change in industry shipments at the three-digit SIC code level deflated by industry price deflators to give the real change in industry shipments. Industry capital intensity is capital expenditures and lagged industry profitability are both divided by industry sales at the three-digit SIC code level. Firm-industry productivity is a firm-industry fixed effect from a production equation estimated using five years of lagged data. Relative odds ratios are the change in the relative likelihood of financial dependence from a one unit increase in the variable. All regressions contain industry and year fixed effects. (Robust standard errors that correct for autocorrelation within segments in parentheses).

Dependent Variable: Dependence $=1$ if Divisional Investment $>$ Divisional Cash Flow

\begin{tabular}{|c|c|c|c|}
\hline & \multirow[b]{2}{*}{ All Industries } & \multicolumn{2}{|c|}{ Change in Long-Run Shipments } \\
\hline & & Decline (-) & Growth $(+)$ \\
\hline \multicolumn{4}{|l|}{ Variables: } \\
\hline $\begin{array}{l}\text { Annual (Short-run) Change in Industry Shipments } \\
\text { standard error }\end{array}$ & $\begin{array}{l}-0.202^{\mathrm{a}} \\
(.054)\end{array}$ & $\begin{array}{l}-0.221^{\mathrm{a}} \\
(.076)\end{array}$ & $\begin{array}{r}0.112 \\
(.081)\end{array}$ \\
\hline relative odds ratio & 0.798 & 0.802 & 1.119 \\
\hline $\begin{array}{l}\text { Lagged Industry Profitability (Value Added/Shipments) } \\
\text { standard error }\end{array}$ & $\begin{array}{l}-0.699^{\mathrm{a}} \\
(.158)\end{array}$ & $\begin{array}{l}-1.014^{\mathrm{a}} \\
(.238)\end{array}$ & $\begin{array}{l}-0.458^{b} \\
(.213)\end{array}$ \\
\hline relative odds ratio & 5.896 & 0.363 & 0.633 \\
\hline $\begin{array}{r}\text { Industry Capital Intensity } \\
\text { standard error }\end{array}$ & $\begin{array}{l}2.115^{\mathrm{a}} \\
(.350)\end{array}$ & $\begin{array}{l}5.614^{\mathrm{a}} \\
(.395)\end{array}$ & $\begin{array}{l}0.819^{b} \\
(.412)\end{array}$ \\
\hline relative odds ratio & 5.896 & 274.239 & 2.268 \\
\hline $\begin{array}{l}\text { Firm-Industry Productivity: Fixed Effect (lagged) } \\
\text { standard error }\end{array}$ & $\begin{array}{l}-0.779^{\mathrm{a}} \\
(.005)\end{array}$ & $\begin{array}{l}-0.772^{\mathrm{a}} \\
(.007)\end{array}$ & $\begin{array}{l}-0.789^{\mathrm{a}} \\
(.006)\end{array}$ \\
\hline relative odds ratio & 0.459 & 0.462 & 0.454 \\
\hline $\begin{array}{c}\text { (Firm-Industry Productivity) })^{2} \text { (lagged) } \\
\text { standard error }\end{array}$ & $\begin{array}{l}0.044^{\mathrm{a}} \\
(.003)\end{array}$ & $\begin{array}{l}0.005 \\
(.005)\end{array}$ & $\begin{array}{l}0.071^{\mathrm{a}} \\
(.003)\end{array}$ \\
\hline relative odds ratio & 1.044 & 1.005 & 1.074 \\
\hline $\begin{array}{l}\log (\text { firm size }) \text { (lagged) } \\
\text { standard error }\end{array}$ & $\begin{array}{l}-0.577^{\mathrm{a}} \\
(.013)\end{array}$ & $\begin{array}{l}-0.582^{\mathrm{a}} \\
(.022)\end{array}$ & $\begin{array}{l}-0.576^{\mathrm{a}} \\
(.017)\end{array}$ \\
\hline relative odds ratio & 0.562 & 0.559 & 0.562 \\
\hline $\begin{array}{l}\log (\text { firm size })^{2} \text { (lagged) } \\
\text { standard error }\end{array}$ & $\begin{array}{l}0.022^{\mathrm{a}} \\
(.001)\end{array}$ & $\begin{array}{l}0.022^{\mathrm{a}} \\
(.001)\end{array}$ & $\begin{array}{l}0.022^{\mathrm{a}} \\
(.001)\end{array}$ \\
\hline relative odds ratio & 0.562 & 1.001 & 1.001 \\
\hline Number of Observations & 409,815 & 159,382 & 250,433 \\
\hline Psuedo R-squared & 0.14 & 0.133 & 0.13 \\
\hline
\end{tabular}

${ }^{\mathrm{a}, \mathrm{b}, \mathrm{c}}$ Significantly different from zero at the one-, five-, ten-percent level. 


\section{Table 4: Firm Organization Status}

Panel logit regressions examining the probability a segment of a firm will be part of a conglomerate firm. Long-run change in industry shipments is the change in industry shipments at the three-digit level over 1972-1997 divided by industry price deflators to give the real change. Annual change in industry shipments is the annual change in industry shipments. Industry capital intensity is capital expenditures divided by industry sales at the three-digit SIC code level, calculated in each year. Firmindustry productivity is a firm-industry fixed effect from a production equation estimated using five years of lagged data. Relative odds ratios are the change in the relative likelihood of financial dependence from a one unit increase in the variable. All regressions contain industry and year fixed effects. (Robust standard errors that correct for autocorrelation within segments in parentheses).

\section{Dependent Variable Conglomerate Firm $=1$}

Variables:

Long-run (25 year) change in industry shipments

$0.243^{\mathrm{a}}$

standard error

relative odds ratio

Annual change in Industry Shipments

$-0.619^{a}$

standard error

relative odds ratio

0.538

Industry Capital Intensity

$5.175^{\mathrm{a}}$

standard error

relative odds ratio

176.788

Firm-Industry Productivity: Fixed Effect (lagged)

$-0.119^{a}$

standard error

relative odds ratio

0.888

(Firm-Industry Productivity) $^{2}$ (lagged)

$0.158^{\mathrm{a}}$

standard error

relative odds ratio

$\log$ (firm size) (lagged)

standard error

relative odds ratio

$\log (\text { firm size })^{2}$ (lagged)

$-0.074^{\mathrm{a}}$

standard error

relative odds ratio

0.928

Number of Observations

409,815

Psuedo R-squared

0.57

${ }^{\mathrm{a}, \mathrm{b}, \mathrm{c}}$ Significantly different from zero at the one-, five-, ten-percent level. 


\section{Table 5: Plant Acquisition}

Regressions examine the relationship between plant acquisition, predicted financial dependence and firm organization. Predicted dependence is the predicted probability of financial dependence using the specification of Table 3 . The growth (Consolidating, Technological Change) quadrant is when the change in real value of shipments is in the upper (upper, lower) fiftieth percentile and change in the number of firms is in the upper (lower, upper) fiftieth percentile of industries over 10 and 25 year periods. Conglomerate firm status is the predicted probability using the specifications of Table 4. Productivity of segment is the weighted average of plant-specific productivity for that segment. All righthand-side variables represent values prior to the year of the acquisition. Relative odds ratios, which represent a change in the relative odds of acquisition, can be obtained by taking the natural exponent of reported coefficients. All regressions contain industry and year fixed effects. (Robust standard errors that correct for autocorrelation within segments in parentheses).

\section{Length of time used to determine life-cycle quadrant:}

Dependent Variable: Plant Acquisition 10 Year Window 25 Year Window

\begin{tabular}{|c|c|c|c|c|}
\hline Variables: & $\underline{\text { coefficient }}$ & $\begin{array}{c}\text { standard } \\
\text { error }\end{array}$ & $\underline{\text { coefficient }}$ & $\begin{array}{c}\text { standard } \\
\text { error }\end{array}$ \\
\hline \multicolumn{5}{|l|}{ Predicted financial dependencr } \\
\hline * Quadrant 1 Indicator: Declining & 0.334 & $(.244)$ & 0.179 & $(.162)$ \\
\hline * Quadrant 2 Indicator: Tech. Change & $-0.278^{b}$ & $(.131)$ & $-0.250^{\mathrm{a}}$ & $(.113)$ \\
\hline * Quadrant 3 Indicator: Consolidating & $-0.355^{b}$ & $(.156)$ & -0.214 & $(.198)$ \\
\hline * Quadrant 4 Indicator: Growth & $1.066^{\mathrm{b}}$ & $(.485)$ & $-1.037^{b}$ & $(.456)$ \\
\hline Conglomerate multi-industry indicator (predicted) & $3.135^{\mathrm{a}}$ & $(.070)$ & $3.110^{\mathrm{a}}$ & $(.080)$ \\
\hline Segment rank within firm (1=largest) & $0.070^{\mathrm{a}}$ & $(.005)$ & $-0.069^{a}$ & $(.005)$ \\
\hline Conglomerate*dependence*Quadrant 1 indicator & -0.042 & $(.244)$ & 0.085 & $(.203)$ \\
\hline * Quadrant 2 Indicator: Tech. Change & $0.512^{\mathrm{a}}$ & $(.177)$ & $0.330^{\mathrm{a}}$ & $(.120)$ \\
\hline * Quadrant 3 Indicator: Consolidating & $0.555^{\mathrm{a}}$ & $(.152)$ & $0.779^{\mathrm{a}}$ & $(.230)$ \\
\hline * Quadrant 4 Indicator: Growth & $1.319^{\mathrm{a}}$ & $(.440)$ & $1.420^{\mathrm{a}}$ & $(.412)$ \\
\hline Average Plant-level Productivity of segment (lagged) & 0.021 & $(.083)$ & 0.022 & $(.083)$ \\
\hline Diversity: standard deviation of growth across segments & -0.129 & $(.120)$ & -0.047 & $(.068)$ \\
\hline Number of Plants in Segment (lagged) & $0.028^{\mathrm{a}}$ & $(.002)$ & $0.028^{\mathrm{a}}$ & $(.002)$ \\
\hline Quadrant 2 Indicator: Tech. Change & 0.020 & $(.150)$ & 0.387 & $(.714)$ \\
\hline Quadrant 3 Indicator: Consolidating & 0.171 & $(.116)$ & $2.786^{\mathrm{a}}$ & $(1.015)$ \\
\hline Quadrant 4 Indicator: Growth & 0.089 & $(.115)$ & -0.186 & $(1.426)$ \\
\hline Constant & $-4.785^{a}$ & $(.155)$ & $-7.434^{a}$ & $(1.012)$ \\
\hline Number of segment-years & 408,430 & & & 408,430 \\
\hline Psuedo R-squared & $14.96 \%$ & & & $15.05 \%$ \\
\hline
\end{tabular}

${ }^{a, b, c}$ Significantly different from zero at the one-, five-, ten-percent level. 
Table 6A: Plant Acquisition in Growth Industries

Regressions examine the relationship between plant acquisition, predicted financial dependence and firm organization. Predicted dependence is the predicted probability of financial dependence using the specification of Table 3. Conglomerate firm status are the predicted probability using the specifications of Table 4. Productivity of segment is the weighted average of plant-specific productivity residuals for that segment. All independent variables represent values prior to the year of the acquisition. Relative odds ratios, which represent a change in the relative odds of acquisition, can be obtained by taking the natural exponent of reported coefficients. All regressions contain industry and year fixed effects. (Robust standard errors that correct for autocorrelation within segments in parentheses).

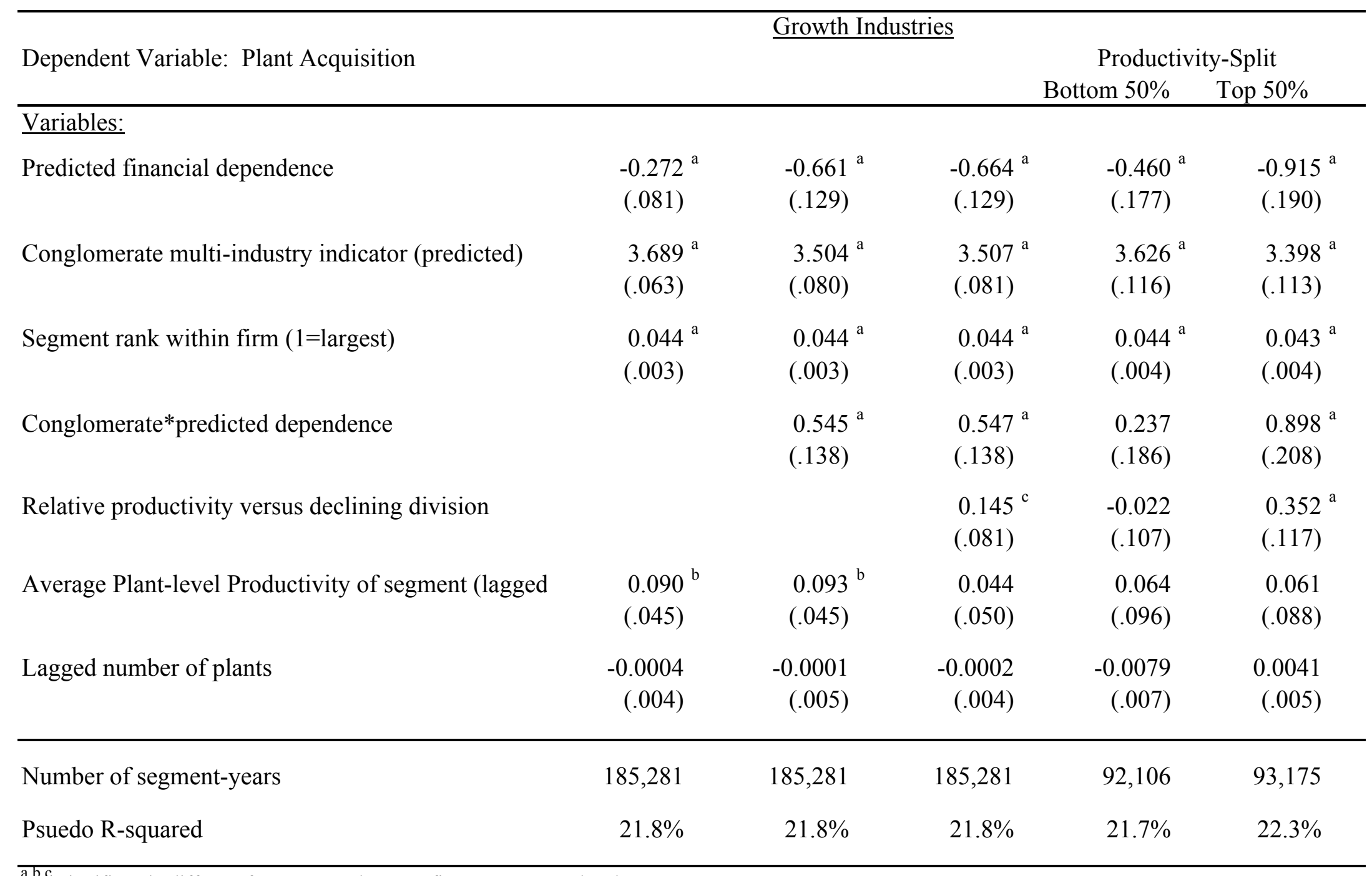

$\overline{\mathrm{a}, \mathrm{b}, \mathrm{c}}$ Significantly different from zero at the one-, five-, ten-percent level. 


\section{Table 6B: Economic Significance}

Table presents predicted probabilities of a within-segment acquisition varying the predicted probability of financial dependence from the 10th to the 90th percentile. All other variables are held at the sample medians for the respective subset of data (multi- and single-segment). Predicted probabilities are calculated using coefficients from Table 6A, column 2, for growth industries and a similar specification for declining industries. High (low) productivity segments are segments above (below) the industry-year median. Predicted probabilities for high productivity segments use coefficients from Table 6A, column 5. The last row for each quadrant uses the medians of the data from the multi-segment firm subset but assume the firm is single segment, thus setting the multi-segment firm indicator equal to zero.

Predicted financial dependence at the

following percentiles:

10th 25th $\quad 50$ th $\quad 75$ th $\quad 90$ th

\section{Declining Industries: Quadrant 1}

Multi-segment firms

Single-segment

Single-segment using medians of

data from multi-segment firms

\section{Multi-segment firms}

Multi-segment firms: high-productivity segments

Single-segment

Single-segment firms: high-productivity segments

Single-segment using medians of data from multi-segment firms

$\begin{array}{lllll}4.38 \% & 3.88 \% & 3.52 \% & 3.96 \% & 4.54 \% \\ 0.66 \% & 0.41 \% & 0.18 \% & 0.10 \% & 0.10 \% \\ 3.49 \% & 2.34 \% & 1.11 \% & 0.40 \% & 0.19 \%\end{array}$

\section{Growth Industries: Quadrant 4}

\begin{tabular}{lllll}
$6.08 \%$ & $5.94 \%$ & $6.26 \%$ & $6.58 \%$ & $7.30 \%$ \\
$6.32 \%$ & $6.15 \%$ & $6.52 \%$ & $7.07 \%$ & $7.97 \%$ \\
$0.69 \%$ & $0.64 \%$ & $0.57 \%$ & $0.50 \%$ & $0.44 \%$ \\
$0.65 \%$ & $0.62 \%$ & $0.57 \%$ & $0.52 \%$ & $0.49 \%$ \\
$5.46 \%$ & $4.95 \%$ & $4.55 \%$ & $4.10 \%$ & $3.28 \%$ \\
\hline
\end{tabular}




\section{Table 7: Productivity Changes Post Acquisition}

Table presents changes in plant productivity for years after plant acquisition. Productivity is the sum of a firm fixed effect plus the residual from an estimated industry production function. Changes in productivity are industry and year adjusted. Declining (technological change, consolidation, growth) industries are industries that have long-run change in industry shipments over 1972-1987 in the lowest (lowest, highest, highest) fiftieth percentile and the long-run change in the number of firms in the lowest (highest, lowest, highest) fiftieth percentile. (Standard error of mean in parentheses).

\begin{tabular}{|c|c|c|c|c|}
\hline Industry Category & $\underline{\text { Years }-1 \text { to } 1}$ & Years -1 to 2 & Years -1 to 3 & Years -1 to 4 \\
\hline \multicolumn{5}{|l|}{ Declining Industries } \\
\hline \multicolumn{5}{|l|}{ Plants purchased by Conglomerate Firms } \\
\hline Average Productivity Change & 0.007 & 0.009 & 0.029 & $0.052^{b}$ \\
\hline Standard Error & $(.020)$ & $(.023)$ & $(.025)$ & $(.027)$ \\
\hline Number of Plants & 1,365 & 1,146 & 1,011 & 888 \\
\hline \multicolumn{5}{|l|}{ Plants purchased by Single-Segment Firms } \\
\hline Average Productivity Change & 0.028 & 0.022 & 0.007 & 0.001 \\
\hline Standard Error & $(.021)$ & $(.024)$ & $(.029)$ & $(.034)$ \\
\hline Number of Plants & 1,057 & 882 & 690 & 552 \\
\hline \multicolumn{5}{|l|}{ Technological Change Industries } \\
\hline \multicolumn{5}{|l|}{ Plants purchased by Conglomerate Firms } \\
\hline Average Productivity Change & $0.034^{\mathrm{a}}$ & $0.045^{\mathrm{a}}$ & $0.039^{\mathrm{a}}$ & $0.032^{b}$ \\
\hline Standard Error & $(.012)$ & $(.013)$ & $(.012)$ & $(.016)$ \\
\hline Number of Plants & 3,681 & 3,305 & 2,980 & 2626 \\
\hline \multicolumn{5}{|l|}{ Plants purchased by Single-Segment Firms } \\
\hline Average Productivity Change & -0.012 & -0.029 & $-0.042^{c}$ & -0.042 \\
\hline Standard Error & $(.018)$ & $(.021)$ & $(.024)$ & $(.027)$ \\
\hline Number of Plants & 1,554 & 1,289 & 1,004 & 822 \\
\hline \multicolumn{5}{|l|}{ Consolidating Industries } \\
\hline \multicolumn{5}{|l|}{ Plants purchased by Conglomerate Firms } \\
\hline Average Productivity Change & 0.010 & 0.016 & 0.017 & 0.022 \\
\hline Standard Error & $(.012)$ & $(.014)$ & $(.015)$ & $(.016)$ \\
\hline Number of Plants & 3,400 & 3,006 & 2,710 & 2454 \\
\hline \multicolumn{5}{|l|}{ Plants purchased by Single-Segment Firms } \\
\hline Average Productivity Change & 0.004 & 0.002 & -0.012 & -0.007 \\
\hline Standard Error & $(.017)$ & $(.020)$ & $(.024)$ & $(.025)$ \\
\hline Number of Plants & 1,829 & 1,458 & 1,167 & 941 \\
\hline \multicolumn{5}{|l|}{ Growth Industries } \\
\hline \multicolumn{5}{|l|}{ Plants purchased by Conglomerate Firms } \\
\hline Average Productivity Change & $0.041^{\mathrm{a}}$ & $0.053^{\mathrm{a}}$ & $0.048^{\mathrm{a}}$ & $0.046^{\mathrm{a}}$ \\
\hline Standard Error & $(.008)$ & $(.009)$ & $(.010)$ & $(.011)$ \\
\hline Number of Plants & 8,016 & 6,922 & 6,068 & 5191 \\
\hline \multicolumn{5}{|l|}{ Plants purchased by Single-Segment Firms } \\
\hline Average Productivity Change & 0.005 & $-0.025^{b}$ & -0.018 & 0.007 \\
\hline Standard Error & $(.011)$ & $(.012)$ & $(.015)$ & $(.017)$ \\
\hline Number of Plants & 4,600 & 3,720 & 2,820 & 2186 \\
\hline
\end{tabular}




\section{Table 8: Capital Expenditures}

Logistic regressions examine the relationship between firm organization, predicted financial dependence and firm segment-level investment. Predicted dependence is the predicted probability of dependence using the specification of Table 3. Conglomerate firm status is the predicted probability using the specifications of Table 4. Productivity of plant is the plant-specific productivity. Declining (technological change, consolidation, growth) industries are industries that have long-run change in industry shipments over 1972-1987 in the lowest (lowest, highest, highest) fiftieth percentile and the long-run change in the number of firms in the lowest (highest, lowest, highest) fiftieth percentile. All regressions contain industry and year fixed effects. (Robust standard errors that correct for autocorrelation within segments in parentheses).

Dependent Variable: Capital Expenditures / Lagged Capital Stock (Industry-Year Adjusted)

\begin{tabular}{|c|c|c|c|c|}
\hline Industry Category & Declining & Tech. Change & Consolidation & Growth \\
\hline \multicolumn{5}{|l|}{ Variables: } \\
\hline Predicted financial dependence & $\begin{array}{r}-0.038 \\
(.057)\end{array}$ & $\begin{array}{l}-0.038^{\mathrm{b}} \\
(.018)\end{array}$ & $\begin{array}{l}-0.066^{\mathrm{b}} \\
(.028)\end{array}$ & $\begin{array}{l}-0.071^{\mathrm{a}} \\
(.028)\end{array}$ \\
\hline Conglomerate multi-industry indicator (predicted) & $\begin{array}{l}0.014 \\
(.012)\end{array}$ & $\begin{array}{l}0.002 \\
(.002)\end{array}$ & $\begin{array}{l}0.006 \\
(.006)\end{array}$ & $\begin{array}{l}0.003 \\
(.003)\end{array}$ \\
\hline Conglomerate* predicted dependence & $\begin{array}{l}0.019 \\
(.013)\end{array}$ & $\begin{array}{l}0.020^{\mathrm{a}} \\
(.004)\end{array}$ & $\begin{array}{l}0.092^{\mathrm{a}} \\
(.015)\end{array}$ & $\begin{array}{l}0.119^{\mathrm{a}} \\
(.013)\end{array}$ \\
\hline Segment rank within firm (1=largest) & $\begin{array}{l}-0.001^{\mathrm{c}} \\
(.0004)\end{array}$ & $\begin{array}{l}-0.002^{\mathrm{a}} \\
(.0005)\end{array}$ & $\begin{array}{l}0.0010^{\mathrm{a}} \\
(.0003)\end{array}$ & $\begin{array}{c}0.002^{\mathrm{a}} \\
(.0003)\end{array}$ \\
\hline Average Plant-level Productivity of segment (lagged) & $\begin{array}{l}0.025^{\mathrm{a}} \\
(.006)\end{array}$ & $\begin{array}{l}0.012^{\mathrm{a}} \\
(.002)\end{array}$ & $\begin{array}{l}0.038^{\mathrm{a}} \\
(.012)\end{array}$ & $\begin{array}{l}0.062^{\mathrm{a}} \\
(.011)\end{array}$ \\
\hline Number of industry plants (lagged) & $\begin{array}{l}-0.003^{\mathrm{a}} \\
(.0003)\end{array}$ & $\begin{array}{l}-0.0002^{b} \\
(.0001)\end{array}$ & $\begin{array}{r}-0.0001 \\
(.0003)\end{array}$ & $\begin{array}{l}-0.0020^{\mathrm{a}} \\
(.0003)\end{array}$ \\
\hline Constant & $\begin{array}{l}0.301^{\mathrm{a}} \\
(.021)\end{array}$ & $\begin{array}{l}0.382^{\mathrm{a}} \\
(.024)\end{array}$ & $\begin{array}{l}0.291^{\mathrm{b}} \\
(.029)\end{array}$ & $\begin{array}{l}0.352^{\mathrm{a}} \\
(.029)\end{array}$ \\
\hline Observations & 92,282 & 74,472 & 68,869 & 195,266 \\
\hline Number of firm-industry segments & 18,091 & 14,235 & 14,289 & 39,672 \\
\hline Adj. R-squared & 0.20 & 0.19 & 0.21 & 0.26 \\
\hline
\end{tabular}

${ }^{\mathrm{a}, \mathrm{b}, \mathrm{c}}$ Significantly different from zero at the one-, five-, ten-percent level. 


\section{Table 9: New Plants}

Logistic regressions examine the relationship between firm organization, predicted financial dependence and new plant openings. Predicted dependence is the predicted probability of dependence using the specification of Table 3. Conglomerate is the predicted probability that the firm produces in at least two different three-digit industries using the specification of Table 4. Productivity of plant is the plant-specific productivity. Declining (technological change, consolidation, growth) industries are industries that have long-run change in industry shipments over 1972-1987 in the lowest (lowest, highest, highest) fiftieth percentile and the long-run change in the number of firms in the lowest (highest, lowest, highest) fiftieth percentile. (Robust standard errors in parentheses). Odds ratios are the change in the relative likelihood of plant exit from a one unit increase in the variable. Year and industry fixed effects are included.

Dependent Variable: New Plant Opening

\section{Industry Category}

Declining Tech. ChangeConsolidation Growth

\begin{tabular}{|c|c|c|c|c|}
\hline Variables: & & & & \\
\hline Predicted financial dependence & 0.023 & 0.119 & $-0.557^{\mathrm{a}}$ & $-0.461^{:}$ \\
\hline standard error & $(.128)$ & $(.137)$ & $(.158)$ & $(.101)$ \\
\hline relative odds ratio & 1.023 & 1.126 & 0.573 & 0.631 \\
\hline Conglomerate multi-industry indicator (predicted) & $2.032^{\mathrm{a}}$ & $2.084^{\mathrm{a}}$ & $2.203^{\mathrm{a}}$ & $1.818^{\prime}$ \\
\hline standard error & $(.094)$ & $(.105)$ & $(.122)$ & $(.075)$ \\
\hline relative odds ratio & 7.629 & 8.037 & 9.052 & 6.160 \\
\hline Conglomerate* predicted dependence & -0.240 & 0.367 & $1.248^{b}$ & $0.780^{\prime}$ \\
\hline standard error & $(.255)$ & $(.294)$ & $(.252)$ & $(.146)$ \\
\hline relative odds ratio & 0.787 & 1.443 & 3.483 & 2.181 \\
\hline Segment rank within firm (1=largest $)$ & $-0.066^{a}$ & $-0.068^{a}$ & $-0.107^{\mathrm{a}}$ & -0.084 \\
\hline standard error & $(.012)$ & $(.107)$ & $(.020)$ & $(.007)$ \\
\hline relative odds ratio & 0.936 & 0.934 & 0.899 & 0.920 \\
\hline Average Plant-level Productivity of segment (lagged) & $0.153^{\mathrm{c}}$ & 0.118 & 0.130 & 0.062 \\
\hline standard error & $(.088)$ & $(.092)$ & $(.097)$ & $(.056)$ \\
\hline relative odds ratio & 1.165 & 1.125 & 1.139 & 1.064 \\
\hline Number of plants in segment (lagged) & $0.052^{\mathrm{a}}$ & $0.078^{\mathrm{a}}$ & $0.046^{\mathrm{a}}$ & $0.096^{:}$ \\
\hline standard error & $(.004)$ & $(.009)$ & $(.004)$ & $(.005)$ \\
\hline relative odds ratio & 1.053 & 1.082 & 1.047 & 1.101 \\
\hline Number of segment-years & 86,968 & 71,358 & 66,875 & 189,221 \\
\hline Number of firm-industry segments & 18,210 & 14,322 & 14,473 & 39,891 \\
\hline Psuedo R-squared & 0.124 & 0.130 & 0.144 & 0.125 \\
\hline
\end{tabular}

${ }^{\mathrm{a}, \mathrm{b}, \mathrm{c}}$ Significantly different from zero at the one-, five-, ten-percent level. 


\section{Table 10: Plant Exit}

Plant-level logit regressions examine the relationship between firm organization, predicted financial dependence and plant closing. Predicted dependence is the predicted probability of dependence using the specification of Table 3. Conglomerate firm status is the predicted probability using the specification of Table 4. Declining (technological change, consolidation, growth) industries are industries that have long-run change in industry shipments over 1972-1987 in the lowest (lowest, highest, highest) fiftieth percentile and the long-run change in the number of firms in the lowest (highest, lowest, highest) fiftieth percentile. Odds ratios are the change in the relative likelihood of plant exit from a one unit increase in the variable. All regressions contain industry and year fixed effects. (Robust standard errors that correct for autocorrelation within segments in parentheses).

Dependent Variable: Plant Exit

\section{Industry Category}

Declining Tech. Change Consolidation

Growth

\begin{tabular}{|c|c|c|c|c|}
\hline \multicolumn{5}{|l|}{ Variables: } \\
\hline Predicted financial dependence & 0.187 & 0.031 & -0.041 & -0.200 \\
\hline standard error & $(.166)$ & $(.232)$ & $(.174)$ & $(.123)$ \\
\hline relative odds ratio & 1.206 & 1.031 & 0.960 & 0.819 \\
\hline Conglomerate multi-industry indicator (predicted) & -0.080 & -0.125 & $-0.428^{a}$ & $-0.509^{a}$ \\
\hline standard error & $(.139)$ & $(.166)$ & $(.139)$ & $(.090)$ \\
\hline relative odds ratio & 0.923 & 0.882 & 0.652 & 0.601 \\
\hline Conglomerate* predicted dependence & $-1.255^{\mathrm{a}}$ & -0.345 & -0.363 & -0.120 \\
\hline standard error & $(.325)$ & $(.358)$ & $(.371)$ & $(.215)$ \\
\hline relative odds ratio & 0.285 & 0.708 & 0.696 & 0.887 \\
\hline Segment rank within firm (1=largest) & $0.044^{\mathrm{a}}$ & $0.030^{\mathrm{a}}$ & $0.044^{\mathrm{a}}$ & $0.031^{\mathrm{a}}$ \\
\hline standard error & $(.004)$ & $(.005)$ & $(.005)$ & $(.003)$ \\
\hline relative odds ratio & 1.045 & 1.030 & 1.045 & 1.031 \\
\hline Average Plant-level Productivity of segment (lagged) & $-0.369^{a}$ & $-0.441^{a}$ & $-0.386^{\mathrm{a}}$ & -0.444 \\
\hline standard error & $(.015)$ & $(.016)$ & $(.016)$ & $(.011)$ \\
\hline relative odds ratio & 0.691 & 0.643 & 0.680 & 0.641 \\
\hline Number of plants in segment (lagged) & $0.009^{\mathrm{a}}$ & $0.008^{\mathrm{a}}$ & $0.004^{\mathrm{a}}$ & $0.015^{\mathrm{a}}$ \\
\hline standard error & $(.001)$ & $(.001)$ & $(.001)$ & $(.002)$ \\
\hline relative odds ratio & 1.009 & 1.008 & 1.004 & 1.015 \\
\hline Number of plant-years & 151,247 & 115,495 & 128,401 & 276,658 \\
\hline Number of firm-industry segments & 18,209 & 14,322 & 14,472 & 38,891 \\
\hline Psuedo R-squared & 0.03 & 0.04 & 0.04 & 0.04 \\
\hline
\end{tabular}

${ }^{\mathrm{a}, \mathrm{b}, \mathrm{c}}$ Significantly different from zero at the one-, five-, ten-percent level. 